\title{
Biodiversity and systematics of basidiomycetous yeasts as determined by large-subunit rDNA D1/D2 domain sequence analysis
}

\author{
Jack W. Fell, ${ }^{1}$ Teun Boekhout, ${ }^{2}$ Alvaro Fonseca, ${ }^{3}$ Gloria Scorzetti ${ }^{1}$ \\ and Adele Statzell-Tallman ${ }^{1}$
}

1 Rosenstiel School of Marine and Atmospheric Science, Key Biscayne, FL, USA

2 Yeast Division, Centraalbureau voor Schimmelcultures, Delft, The Netherlands

3 Biotechnology Unit, Faculty of Sciences and Technology/New University of Lisbon, Caparica, Portugal

\author{
Author for correspondence: Jack W. Fell. Tel: +1 305361 4603. Fax: +1 3053614600 \\ e-mail: jfell@rsmas.miami.edu
}

The molecular systematics of 337 strains of basidiomycetous yeasts and yeastlike fungi, representing 230 species in 18 anamorphic and 24 teleomorphic genera, was determined by sequence analysis of the D1/D2 region of the largesubunit rDNA. The data were compared with published sequences of other basidiomycetous fungi. The results demonstrated that the yeast species and genera are phylogenetically distributed among the Microbotryum, Sporidiobolus, Agaricostilbum and Erythrobasidium clades of the Urediniomycetes; the Tremellales, Trichosporonales ord. nov., Filobasidiales and Cystofilobasidiales clades of the Hymenomycetes; and the Ustilaginales, Microstromatales and Malasseziales clades of the Ustilaginomycetes. Genera such as Bensingtonia, Cryptococcus, Rhodotorula and Sporobolomyces are polyphyletic, i.e. they occur in two or more clades. In contrast, other genera, e.g. Bullera, Cystofilobasidium, Fellomyces, Filobasidiella, Filobasidium, Kondoa, Kurtzmanomyces, Leucosporidium, Rhodosporidium, Sporidiobolus and Udeniomyces, are monophyletic. The majority of the species can be identified using D1/D2 analyses, although the internal transcribed spacer region is required to distinguish closely related species. The intergenic spacer region is recommended for additional differentiation of species and strains.

Keywords: yeasts, Urediniomycetes, Hymenomycetes, Ustilaginomycetes, Trichosporonales ord. nov.

\section{INTRODUCTION}

The basidiomycetous yeasts, as currently recognized, are distributed among the three classes of the Basidiomycota: Ustilaginomycetes, Urediniomycetes and Hymenomycetes. These yeasts have considerable economic, agricultural and medical importance and estimates indicate that the number of known yeasts may represent about $1 \%$ of the species that exist in nature. There is an increased interest in discovering these species for economic exploitation and there is a need to understand their biodiversity and ecological roles. Identification and phylogenetic placement of the basidiomycetous yeasts are not always easy to accom-

Abbreviations: IGS, intergenic spacer; ITS, internal transcribed spacer; LrDNA, large-subunit rDNA. plish, partly because of their polyphyletic nature. The unifying characteristic of these fungi is a predominant unicellular growth phase. Separation of yeasts into the three classes of fungi is based on septal morphology, cell wall composition and rDNA analysis. Generic diagnoses are directed to sexual and vegetative biology, in addition to physiological tests such as growth on inositol or D-glucuronic acid and formation of extracellular starch-like compounds. Species are usually differentiated by physiological attributes, particularly the utilization of carbon and nitrogen sources, and by measurement of DNA reassociations between closely related species. By the very nature of these tests, identifications can be slow, difficult and expensive to perform; results of physiological and morphological tests often demonstrate considerable variability within and between species. Consequently, there is an urgent need for diagnostic tools to provide rapid and accurate 
J. W. Fell and others

Table 1. Hymenomycetous yeasts examined in the D1/D2 and internal transcribed spacer rDNA regions

\begin{tabular}{|c|c|c|c|}
\hline \multirow[t]{2}{*}{ Strain } & \multirow[t]{2}{*}{ Strain no.* } & \multicolumn{2}{|c|}{ GenBank accession no. } \\
\hline & & D1/D2 & ITS $\dagger$ \\
\hline Apiotrichum porosum & CBS $2040^{\mathrm{T}}$ & AF189833 & \\
\hline Bullera armeniaca & CBS $7091^{\mathrm{T}}$ & AF189883 & \\
\hline Bullera crocea & CBS $6714^{\mathrm{T}}$ & AF075508 & \\
\hline Bullera dendrophila & CBS $6074^{\mathrm{T}}$ & AF189870 & \\
\hline Bullera derxii & CBS $7225^{\mathrm{T}}$ & AF189857 & \\
\hline Bullera globispora & CBS $6981^{\mathrm{T}}$ & AF075509 & \\
\hline Bullera miyagiana & CBS $7526^{\mathrm{T}}$ & AF189858 & \\
\hline Bullera oryzae & CBS $7194^{\mathrm{T}}$ & AF075511 & \\
\hline Bullera pseudoalba & CBS $7227^{\mathrm{T}}$ & AF075504 & \\
\hline Bullera sinensis & CBS $7238^{\mathrm{T}}$ & AF189884 & \\
\hline Bullera unica & CBS $8290^{\mathrm{T}}$ & AF075524 & \\
\hline Bullera variabilis & CBS $7347^{\mathrm{T}}$ & AF189855 & \\
\hline Bulleromyces albus & CBS $501^{\mathrm{T}}$ & AF075500 & \\
\hline Cryptococcus adeliensis & CBS $8351^{\mathrm{T}}$ & AF137603 & AF145328 \\
\hline Cryptococcus aerius & CBS $155^{\mathrm{T}}$ & AF075486 & AF145324 \\
\hline Cryptococcus albidosimilis & CBS $7711^{\mathrm{T}}$ & AF137601 & AF 145325 \\
\hline Cryptococcus albidosimilis & ATCC 34633 & AF137606 & AF145331 \\
\hline Cryptococcus albidus & CBS $142^{\mathrm{T}}$ & AF075474 & AF145321 \\
\hline Cryptococcus albidus & IGC 2426 & AF181514 & \\
\hline Cryptococcus albidus & IGC 4789 & AF181531 & \\
\hline Cryptococcus albidus & IGC 4963 & AF181509 & \\
\hline Cryptococcus albidus & IGC 4990 & AF181511 & \\
\hline Cryptococcus genitalis & CBS $5592^{\mathrm{T}}$ & AF181538 & \\
\hline Torulopsis nadaensis: & CBS $969^{\mathrm{T}}$ & AF181516 & \\
\hline Torulopsis rotundata & CBS $945^{\mathrm{T}}$ & AF181517 & \\
\hline Cryptococcus albidus var. ovalis & CBS $5810^{\mathrm{T}}$ & AF137605 & AF145329 \\
\hline Cryptococcus amylolentus & CBS $6039^{\mathrm{T}}$ & AF105391 & \\
\hline Cryptococcus antarcticus & CBS $7687^{\mathrm{T}}$ & AF075488 & AF 145326 \\
\hline Cryptococcus aquaticus & CBS $5443^{\mathrm{T}}$ & AF075470 & \\
\hline Cryptococcus bhutanensis & CBS $6294^{\mathrm{T}}$ & AF137599 & AF145317 \\
\hline Cryptococcus cellulolyticus & CBS $8294^{\mathrm{T}}$ & AF075525 & \\
\hline Cryptococcus curvatus & CBS $570^{\mathrm{T}}$ & AF189834 & \\
\hline Cryptococcus dimennae & CBS $5770^{\mathrm{T}}$ & AF075489 & \\
\hline Cryptococcus diffluens & CBS $160^{\mathrm{T}}$ & AF075502 & AF 145330 \\
\hline Cryptococcus diffluens var. uruguaiensis & CBS $6436^{\mathrm{T}}$ & AF181543 & \\
\hline Torulopsis albida var. japonicat & CBS $926^{\mathrm{T}}$ & AF181542 & \\
\hline Cryptococcus elinovii & CBS $7051^{\mathrm{T}}$ & AF137604 & AF145318 \\
\hline Cryptococcus flavus & CBS $331^{\mathrm{T}}$ & AF075497 & \\
\hline Cryptococcus friedmannii & CBS $7160^{\mathrm{T}}$ & AF075478 & AF145322 \\
\hline Cryptococcus fuscescens & CBS $7189^{\mathrm{T}}$ & AF075472 & AF145319 \\
\hline Cryptococcus gastricus & CBS $2288^{\mathrm{T}}$ & AF137600 & \\
\hline Cryptococcus gastricus & CBS 1927 & AF181501 & \\
\hline Cryptococcus gilvescens & CBS $7525^{\mathrm{T}}$ & AF181547 & \\
\hline Cryptococcus heveanensis & CBS $569^{\mathrm{T}}$ & AF075467 & \\
\hline Cryptococcus himalayensis & CBS $6293^{\mathrm{T}}$ & AF181502 & \\
\hline Cryptococcus huетрii & CBS $8186^{\mathrm{T}}$ & AF189844 & \\
\hline Cryptococcus humicolus & CBS $571^{\mathrm{T}}$ & AF189836 & \\
\hline Cryptococcus humicolus & CBS 8354 & AF189851 & \\
\hline Cryptococcus humicolus & CBS 8371 & AF189854 & \\
\hline Cryptococcus hungaricus & CBS $4214^{\mathrm{T}}$ & AF075503 & \\
\hline Cryptococcus kuetzingii & CBS $1926^{\mathrm{T}}$ & AF137602 & AF145327 \\
\hline
\end{tabular}


Table 1 (cont.)

\begin{tabular}{|c|c|c|c|}
\hline \multirow[t]{2}{*}{ Strain } & \multirow[t]{2}{*}{ Strain no.* } & \multicolumn{2}{|c|}{ GenBank accession no. } \\
\hline & & D1/D2 & ITS $\dagger$ \\
\hline Cryptococcus kuetzingii & CBS $922^{\mathrm{T}}$ & AF181504 & \\
\hline Cryptococcus laurentii & CBS $139^{\mathrm{T}}$ & AF075469 & \\
\hline Cryptococcus luteolus & CBS $943^{\mathrm{T}}$ & AF075482 & \\
\hline Cryptococcus macerans & CBS $2206^{\mathrm{T}}$ & AF189848 & \\
\hline Cryptococcus macerans & CBS 2425 & AF075477 & \\
\hline Cryptococcus magnus & CBS $140^{\mathrm{T}}$ & AF181851 & AF190008 \\
\hline Cryptococcus magnus & CBS 8361 & AF189852 & \\
\hline Cryptococcus magnus & CBS 8362 & AF189853 & \\
\hline Cryptococcus magnus & CBS 8394 & AF189872 & \\
\hline Cryptococcus magnus & IGC 4556 & AF181528 & \\
\hline Cryptococcus magnus & IGC 4563 & AF181529 & \\
\hline Cryptococcus magnus & IGC 4989 & AF181510 & \\
\hline Cryptococcus magnus & IGC 5260 & AF 181532 & \\
\hline Cryptococcus magnus & IGC 5267 & AF181536 & \\
\hline Cryptococcus ater $\$$ & CBS $4685^{\mathrm{T}}$ & AF181505 & AF190009 \\
\hline Cryptococcus marinus & CBS $5235^{\mathrm{T}}$ & AF189846 & \\
\hline Cryptococcus podzolicus & CBS $6819^{\mathrm{T}}$ & AF075481 & \\
\hline Cryptococcus skinneri & CBS $5029^{\mathrm{T}}$ & AF189835 & \\
\hline Cryptococcus terreus & CBS $1895^{\mathrm{T}}$ & AF075479 & \\
\hline Cryptococcus terricolus & CBS $4517^{\mathrm{T}}$ & AF 181520 & \\
\hline Cryptococcus terricolus & CBS 6435 & AF181545 & \\
\hline Cryptococcus vishniacii & CBS $7110^{\mathrm{T}}$ & AF075473 & AF 145320 \\
\hline Cryptococcus asgardensis & CBS $8141^{\mathrm{T}}$ & AF189839 & \\
\hline Cryptococcus baldrensist & CBS $8142^{\mathrm{T}}$ & AF189840 & \\
\hline Cryptococcus consortionis & A $801-3 \mathrm{aY} 92 / 20^{\mathrm{T}}$ & AF189880 & \\
\hline Cryptococcus hempflingiit & CBS $8143^{\mathrm{T}}$ & AF189841 & \\
\hline Cryptococcus lupit & CBS $8100^{\mathrm{T}}$ & AF189860 & \\
\hline Cryptococcus socialis & CBS $7158^{\mathrm{T}}$ & AF181503 & \\
\hline Cryptococcus vishniacii var. asocialis & CBS $8146^{\mathrm{T}}$ & AF189838 & \\
\hline Cryptococcus wrightensis & CBS $8145^{\mathrm{T}}$ & AF189837 & \\
\hline Cystofilobasidium bisporidii & CBS $6346^{\mathrm{T}}$ & AF189832 & \\
\hline Cystofilobasidium bisporidii & CBS 6347 & AF075464 & \\
\hline Cystofilobasidium capitatum & CBS $6358^{\mathrm{T}}$ & AF075465 & AF139627 \\
\hline Cystofilobasidium lari-marini & CBS $7420^{\mathrm{T}}$ & AF075466 & \\
\hline Cystofilobasidium feraegula & CBS 7201 & AF075487 & \\
\hline Cystofilobasidium infirmo-miniatum & CBS $323^{\mathrm{T}}$ & AF075505 & \\
\hline Fellomyces borneensis & CBS $8282^{\mathrm{T}}$ & AF189877 & \\
\hline Fellomyces chinensis & CBS $8278^{T}$ & AF189878 & \\
\hline Fellomyces fuzhouensis & CBS 6133 & AF075506 & \\
\hline Fellomyces horovitziae & CBS $7515^{\mathrm{T}}$ & AF189856 & \\
\hline Fellomyces penicillatus & CBS $5492^{\mathrm{T}}$ & AF177405 & \\
\hline Fellomyces polyborus & CBS $6072^{\mathrm{T}}$ & AF189859 & \\
\hline Fellomyces sichuanensis & CBS $8318^{\mathrm{T}}$ & AF189879 & \\
\hline Filobasidiella neoformans var. neoformans & CBS $132^{\mathrm{T}}$ & AF075484 & \\
\hline Filobasidiella neoformans var. neoformans & CBS 882 & AF189845 & \\
\hline Filobasidiella neoformans var. bacillispora & CBS $6289^{\mathrm{T}}$ & AF075526 & \\
\hline Filobasidium capsuligenum & CBS 4736 & AF075501 & \\
\hline Filobasidium capsuligenum & CBS 6219 & AF181506 & \\
\hline Filobasidium elegans & CBS 7640 & AF181548 & AF190006 \\
\hline Filobasidium floriforme & CBS $6241^{\mathrm{T}}$ & AF075498 & AF190007 \\
\hline
\end{tabular}


J. W. Fell and others

Table 1 (cont.)

\begin{tabular}{|c|c|c|c|}
\hline \multirow[t]{2}{*}{ Strain } & \multirow[t]{2}{*}{ Strain no.* } & \multicolumn{2}{|c|}{ GenBank accession no. } \\
\hline & & D1/D2 & ITS $\dagger$ \\
\hline Filobasidium globisporum & CBS 7642 & AF075495 & \\
\hline Filobasidium uniguttulatum & CBS $1730^{\mathrm{T}}$ & AF075468 & \\
\hline Filobasidium uniguttulatum & CBS 1727 & AF 181500 & \\
\hline Holtermannia corniformis & CBS 6979 & AF189843 & \\
\hline Kockovaella imperatae & CBS $7554^{\mathrm{T}}$ & AF189862 & \\
\hline Kockovaella thailandica & CBS $7552^{\mathrm{T}}$ & AF075516 & \\
\hline Mrakia frigida & CBS $5270^{T}$ & AF075463 & AF144483 \\
\hline Mrakia nivalist & CBS $5266^{\mathrm{T}}$ & AF189849 & AF 144484 \\
\hline Cryptococcus curiosus & CBS $5688^{\mathrm{T}}$ & AF 189847 & AF144482 \\
\hline Mrakia gelida & CBS $5272^{\mathrm{T}}$ & AF189831 & AF 144485 \\
\hline Mrakia stokesiił & CBS $5917^{\mathrm{T}}$ & AF 189830 & AF144486 \\
\hline Naganishia globosa & CBS $5106^{\mathrm{T}}$ & AF 181539 & \\
\hline Cryptococcus sp. & IGC 5257 & AF 181512 & \\
\hline Hansenula amylofaciens & CBS $1975^{\mathrm{T}}$ & AF 181540 & \\
\hline Phaffia rhodozyma & CBS $5905^{\mathrm{T}}$ & AF189871 & \\
\hline Sirobasidium magnum & CBS 6803 & AF075475 & \\
\hline Sirobasidium intermedium & CBS 7805 & AF075492 & \\
\hline Sterigmatosporidium polymorphum & CBS $8088^{T}$ & AF075480 & \\
\hline Torulopsis liquefaciens & CBS $968^{\mathrm{T}}$ & AF181515 & \\
\hline Cryptococcus sp. & IGC 2406 & AF181513 & \\
\hline Cryptococcus sp. & IGC 2934 & AF181518 & \\
\hline Torulopsis pseudoaeria & CBS $4192^{\mathrm{T}}$ & AF181544 & \\
\hline Cryptococcus sp. & IGC 4643 & AF 181522 & \\
\hline Cryptococcus sp. & IGC 5259 & AF 181525 & \\
\hline Tremella aurantia & CBS 6965 & AF189842 & \\
\hline Tremella brasiliensis & CBS 6966 & AF189864 & \\
\hline Tremella cinnabarina & CBS 8234 & AF189866 & \\
\hline Tremella coalescens & CBS 6967 & AF189865 & \\
\hline Tremella encephala & CBS 6968 & AF189867 & \\
\hline Tremella foliacea & CBS 6969 & AF189868 & \\
\hline Tremella fuciformis & CBS 6970 & AF075476 & \\
\hline Tremella globispora & CBS 6972 & AF189869 & \\
\hline Tremella mesenterica & CBS 6973 & AF075518 & \\
\hline Tremella moriformis & CBS 7810 & AF075493 & \\
\hline Trichosporon aquatile & CBS $5973^{T}$ & AF075520 & \\
\hline Trichosporon asahii & CBS $2479^{\mathrm{T}}$ & AF 105393 & \\
\hline Trichosporon asahii & CBS 8640 & AF189881 & \\
\hline Trichosporon asahii & CBS 7137 & AF189882 & \\
\hline Trichosporon asahii & CBS 8520 & AF 189876 & \\
\hline Trichosporon asteroides & CBS $2481^{\mathrm{T}}$ & AF075513 & \\
\hline Trichosporon brassicae & CBS $6382^{\mathrm{T}}$ & AF075521 & \\
\hline Trichosporon cutaneum & CBS $2466^{\mathrm{T}}$ & AF075483 & \\
\hline Trichosporon coremiiforme & CBS $2482^{\mathrm{T}}$ & AF139983 & \\
\hline Trichosporon coremiiforme & CBS 2478 & AF189863 & \\
\hline Trichosporon domesticum & CBS $8280^{\mathrm{T}}$ & AF075512 & \\
\hline Trichosporon domesticum & CBS 8111 & AF189874 & \\
\hline Trichosporon dulcitum & CBS $8257^{\mathrm{T}}$ & AF075517 & \\
\hline Trichosporon faecale & CBS $4828^{T}$ & AF105395 & \\
\hline Trichosporon gracile & CBS $8189^{\mathrm{T}}$ & AF105399 & \\
\hline Trichosporon gracile & CBS 8518 & AF 189875 & \\
\hline
\end{tabular}


Table 1 (cont.)

\begin{tabular}{|c|c|c|c|}
\hline \multirow[t]{2}{*}{ Strain } & \multirow[t]{2}{*}{ Strain no.* } & \multicolumn{2}{|c|}{ GenBank accession no. } \\
\hline & & D1/D2 & ITS $\dagger$ \\
\hline Trichosporon guehoae & CBS $8521^{\mathrm{T}}$ & AF105401 & \\
\hline Trichosporon inkin & CBS $5585^{\mathrm{T}}$ & AF105396 & \\
\hline Trichosporon jirovecii & CBS $6864^{\mathrm{T}}$ & AF 105398 & \\
\hline Trichosporon laibachii & CBS $5790^{\mathrm{T}}$ & AF075514 & \\
\hline Trichosporon loubierii & CBS $7065^{\mathrm{T}}$ & AF075522 & \\
\hline Trichosporon moniliiforme & CBS $2467^{\mathrm{T}}$ & AF105392 & \\
\hline Trichosporon moniliiforme & CBS 8400 & AF189873 & \\
\hline Trichosporon montevideense & CBS $6721^{\mathrm{T}}$ & AF105397 & \\
\hline Trichosporon mucoides & CBS $7625^{\mathrm{T}}$ & AF075515 & \\
\hline Trichosporon multisporum & CBS $2495^{\mathrm{A}}$ & AF139984 & \\
\hline Trichosporon ovoides & CBS $7556^{\mathrm{T}}$ & AF075523 & \\
\hline Trichosporon pullulans & CBS $2532^{\mathrm{T}}$ & AF105394 & \\
\hline Trichosporon pullulans & CBS 2541 & AF189861 & \\
\hline Trichosporon sporotrichoides & CBS $8246^{\mathrm{T}}$ & AF189885 & \\
\hline Trichosporon veenhuisii & CBS $7136^{\mathrm{T}}$ & AF 105400 & \\
\hline Tsuchiyaea wingfieldii & CBS $7118^{\mathrm{T}}$ & AF177404 & \\
\hline Udeniomyces megalosporus & CBS $7236^{\mathrm{T}}$ & AF075510 & \\
\hline Udeniomyces puniceus & CBS $5689^{\mathrm{T}}$ & AF075519 & \\
\hline Udeniomyces pyricola & CBS $6754^{\mathrm{T}}$ & AF075507 & \\
\hline Xanthophyllomyces dendrorhous & CBS $7918^{\mathrm{T}}$ & AF075496 & \\
\hline
\end{tabular}

* T, Type strain; A, authentic strain.

$\dagger$ Not all strains were examined in the ITS region.

$\$$ Species considered to be synonyms of the lead listed species as determined by sequence analysis and examination of classical taxonomic characteristics.

identifications of species and to gather information on phylogenetic relationships.

To overcome these problems, yeast-identification techniques have been directed to molecular methods, such as utilization of species-specific PCR primers (Fell, 1995; Haynes et al., 1995; Mannarelli \& Kurtzman, 1998; Mitchell et al., 1994), analysis of RFLPs (Magee et al., 1987), PFGE, randomly amplified polymorphic DNA (Boekhout et al., 1997) and single-stranded conformational polymorphisms (Walsh et al., 1995). Significant advances in basidiomycete systematics resulted from sequence analysis of the large and small subunits of rRNA and DNA (Boekhout et al., 1995; Fell \& Kurtzman, 1990; Fell et al., 1995; Guého et al., 1989, 1993; Nakase et al., 1993; Sugiyama \& Suh, 1993; Suh \& Sugiyama, 1993; Suh \& Nakase, 1995; Swann \& Taylor, 1995b; Van de Peer et al., 1992; Yamada \& Kawasaki, 1989; Yamada \& Nakagawa, 1992).

One of the long-standing problems has been understanding the phylogenetic relationships between basidiomycetous yeasts and filamentous fungi. Dimorphism (yeast and filamentous states) has been recognized as representing distinct stages in the life-histories of heterobasidiomycetous fungi such as species of Tremella and Filobasidiella. With the exception of Xanthophyllomyces, all of the teleomorphic basidio- mycetous yeast genera have a filamentous stage. However, the relationships between the basidiomycetous yeasts and other fungi have been an open question. Ultrastructural and molecular analyses have shown that basidiomycetous yeasts are distributed among the three main phylogenetic lines of the Basidiomycota, namely the Hymenomycetes, Urediniomycetes and Ustilaginomycetes (McLaughlin et al., 1995; Swann \& Taylor, 1995a, c).

The purpose of the current communication is to examine the distribution of yeasts among these three classes of fungi. This is the first study to examine the D1/D2 region of the large-subunit rDNA (LrDNA) for all known species of basidiomycetous yeasts (sensu Kurtzman \& Fell, 1998). In addition, this report examines the use of the D1/D2 and internal transcribed spacer (ITS) regions for recognizing species boundaries.

\section{METHODS}

The strains that we examined are listed in Tables 1-3. Strains and synonyms with identical nucleotide sequences are shown indented under a species name. For example, seven strains were examined that had sequences identical to those of Cryptococcus albidus (IGC 2426, 4789, 4963, 4990) and the synonyms Cryptococcus genitalis, Torulopsis rotundata and Torulopsis nadaensis. Type strains of species and synonyms 
J. W. Fell and others

Table 2. Urediniomycetous yeasts examined in the D1/D2 and ITS rDNA regions

\begin{tabular}{|c|c|c|c|}
\hline \multirow[t]{2}{*}{ Strain } & \multirow[t]{2}{*}{ Strain no.* } & \multicolumn{2}{|c|}{ GenBank accession no } \\
\hline & & D1/D2 & ITS $\dagger$ \\
\hline Agaricostilbum hyphaenes & CBS 7811 & AF177406 & \\
\hline Bensingtonia ciliata & CBS $7514^{\mathrm{T}}$ & AF189887 & \\
\hline Bensingtonia ingoldii & CBS $7424^{\mathrm{T}}$ & AF189888 & \\
\hline Bensingtonia intermedia & CBS $7226^{\mathrm{T}}$ & AF189889 & \\
\hline Bensingtonia intermedia & CBS 7281 & AF189890 & \\
\hline Bensingtonia miscanthi & CBS $7282^{\mathrm{T}}$ & AF189891 & \\
\hline Bensingtonia musae & CBS $7965^{\mathrm{T}}$ & AF189892 & \\
\hline Bensingtonia naganoensis & CBS $7286^{\mathrm{T}}$ & AF189893 & \\
\hline Bensingtonia phyllada & CBS $7169^{\mathrm{T}}$ & AF189894 & \\
\hline Bensingtonia subrosea & CBS $7283^{\mathrm{T}}$ & AF189895 & \\
\hline Bensingtonia yamatoana & CBS $7243^{\mathrm{T}}$ & AF189896 & \\
\hline Bensingtonia yuccicola & CBS $7331^{\mathrm{T}}$ & AF189897 & \\
\hline Chionosphaera apobasidialis & CBS $7430^{T}$ & AF177407 & \\
\hline Colacogloea peniophorae & IGC 4825 & AF189898 & \\
\hline Erythrobasidium hasegawianum & CBS $8253^{\mathrm{T}}$ & AF189899 & \\
\hline Heterogastridium pycnidioideum & CBS 591.93 & AF189900 & \\
\hline Kondoa aeria & CBS $8352^{\mathrm{T}}$ & AF189901 & \\
\hline Kondoa aeria & CBS 8378 & AF189902 & \\
\hline Kondoa malvinella & CBS $6082^{\mathrm{T}}$ & AF189903 & \\
\hline Kondoa myxariophilla & CBS $8379^{\mathrm{T}}$ & AF189904 & \\
\hline Kriegeria eriophori & CBS 8387 & AF189905 & \\
\hline Kurtzmanomyces insolitus & CBS $8377^{\mathrm{T}}$ & AF 177408 & \\
\hline Kurtzmanomyces nectairei & CBS $6405^{\mathrm{T}}$ & AF177409 & \\
\hline Kurtzmanomyces tardus & CBS $7421^{\mathrm{T}}$ & AF177410 & \\
\hline Leucosporidium antarcticum & CBS $5942^{\mathrm{T}}$ & AF189906 & \\
\hline Leucosporidium fellii & CBS $7287^{\mathrm{T}}$ & AF189907 & \\
\hline Leucosporidium scottii & CBS $5930^{\mathrm{T}}$ & AF070419 & \\
\hline Leuconostoc scottii & CBS 5932 & AF189908 & \\
\hline Occultifur externus & IGC $4817^{\mathrm{T}}$ & AF189909 & \\
\hline Occultifur externus & IGC 4557 & AF189910 & \\
\hline Occultifur externus & IGC 4823 & AF189911 & \\
\hline Reniforma strues & CBS $8263^{\mathrm{T}}$ & AF189912 & \\
\hline Rhodosporidium babjevae & CBS $7808^{\mathrm{T}}$ & AF070420 & \\
\hline Rhodosporidium babjevae & KB 649 & AF189913 & \\
\hline Rhodosporidium diobovatum & CBS $6085^{\mathrm{T}}$ & AF070421 & \\
\hline Rhodosporidium diobovatum & CBS 6084 & AF189914 & \\
\hline Rhodosporidium fluviale & CBS $6568^{\mathrm{T}}$ & AF070422 & \\
\hline Rhodosporidium kratochvilovae & CBS $7436^{\mathrm{T}}$ & AF071436 & \\
\hline Rhodosporidium kratochvilovae & IGC 4818 & AF189916 & \\
\hline Rhodosporidium kratochvilovae & IGC 4819 & AF189917 & \\
\hline Rhodosporidium kratochvilovae & IGC 4793 & AF189918 & \\
\hline Rhodosporidium lusitaniae & CBS $7604^{\mathrm{T}}$ & AF070423 & \\
\hline Rhodosporidium paludigenum & CBS 6567 & AF070424 & \\
\hline Rhodosporidium sphaerocarpum & CBS $5939^{\mathrm{T}}$ & AF070425 & \\
\hline Rhodosporidium sphaerocarpum & CBS 5941 & AF189919 & \\
\hline Rhodosporidium toruloides & CBS 349 & AF070426 & \\
\hline Rhodotorula araucariae & CBS $6031^{\mathrm{T}}$ & AF070427 & \\
\hline Rhodotorula armeniaca & CBS $8076^{\mathrm{T}}$ & AF 189920 & \\
\hline Rhodotorula aurantiaca & CBS $317^{\mathrm{T}}$ & AF189921 & \\
\hline Rhodotorula auriculariae & CBS $6379^{\mathrm{T}}$ & AF189922 & \\
\hline Rhodotorula bogoriensis & CBS $4101^{\mathrm{T}}$ & AF189923 & \\
\hline
\end{tabular}


Table 2 (cont.)

\begin{tabular}{|c|c|c|c|}
\hline \multirow[t]{2}{*}{ Strain } & \multirow[t]{2}{*}{ Strain no.* } & \multicolumn{2}{|c|}{ GenBank accession no. } \\
\hline & & D1/D2 & ITS $\dagger$ \\
\hline Rhodotorula buffonii & CBS $2838^{\mathrm{T}}$ & AF189924 & \\
\hline Rhodotorula creatinivora & CBS $8620^{\mathrm{T}}$ & AF189925 & \\
\hline Rhodotorula cresolica & CBS $7998^{\mathrm{T}}$ & AF189926 & \\
\hline Rhodotorula diffluens & CBS $5233^{\mathrm{T}}$ & AF075485 & \\
\hline Rhodotorula ferulica & CBS 7402 & AF 189927 & \\
\hline Rhodotorula fujisanensis & CBS $4551^{\mathrm{T}}$ & AF 189928 & \\
\hline Rhodotorula fujisanensis & CBS 6371 & AF189929 & \\
\hline Rhodotorula fujisanensis & CBS 8264 & AF189930 & \\
\hline Rhodotorula futronensis & CBS $8163^{\mathrm{T}}$ & AF189931 & \\
\hline Rhodotorula foliorum & CBS 6370 & AF075499 & \\
\hline Rhodotorula fragraria & CBS $6254^{\mathrm{T}}$ & AF070428 & \\
\hline Rhodotorula glutinis & CBS $20^{\mathrm{T}}$ & AF070430 & \\
\hline Rhodotorula glutinis var. dairenensis & CBS $4406^{\mathrm{T}}$ & AF070429 & \\
\hline Rhodotorula graminis & CBS $2826^{\mathrm{T}}$ & AF070431 & \\
\hline Rhodotorula graminis & KB 650 & AF189932 & \\
\hline Rhodotorula hordea & CBS $6403^{\mathrm{T}}$ & AF189933 & \\
\hline Rhodotorula ingeniosa & CBS $4240^{\mathrm{T}}$ & AF189934 & \\
\hline Rhodotorula javanica & CBS $5236^{\mathrm{T}}$ & AF189935 & \\
\hline Rhodotorula lactosa & CBS $5826^{\mathrm{T}}$ & AF189936 & \\
\hline Rhodotorula laryngis & CBS $2221^{\mathrm{T}}$ & AF189937 & AF190014 \\
\hline Rhodotorula laryngis & IGC 4886 & AF189938 & \\
\hline Rhodotorula laryngis & Y-17494 & AF189939 & \\
\hline Rhodotorula laryngis & $Y-17503$ & AF189940 & \\
\hline Rhodotorula laryngis & $Y-17504$ & AF189941 & \\
\hline Rhodotorula zsoltiit & CBS $5695^{\mathrm{T}}$ & AF189942 & AF190013 \\
\hline Rhodotorula lignophila & CBS $7109^{\mathrm{T}}$ & AF189943 & \\
\hline Rhodotorula marina & CBS $2365^{\mathrm{T}}$ & AF189944 & \\
\hline Rhodotorula minuta & CBS $319^{\mathrm{T}}$ & AF189945 & AF190011 \\
\hline Rhodotorula minuta & CBS 4408 & AF189946 & \\
\hline Rhodotorula minuta & CBS 7296 & AF189947 & \\
\hline Rhodotorula texensis: & CBS $2177^{\mathrm{T}}$ & AF189948 & AF 190010 \\
\hline Rhodotorula tokyoensis & CBS $4407^{\mathrm{T}}$ & AF189949 & AF190012 \\
\hline Rhodotorula mucilaginosa & CBS $316^{\mathrm{T}}$ & AF070432 & \\
\hline Rhodotorula mucilaginosa & IGC 4349 & AF189951 & \\
\hline Rhodotorula mucilaginosa & Y-17485 & AF189952 & \\
\hline Rhodotorula mucilaginosa & Y-17493 & AF189953 & \\
\hline Rhodotorula mucilaginosa & Y-17495 & AF 189954 & \\
\hline Rhodotorula mucilaginosa & Y-17496 & AF189955 & \\
\hline Rhodotorula mucilaginosa & Y-17499 & AF189956 & \\
\hline Rhodotorula mucilaginosa & $Y-17500$ & AF189957 & \\
\hline Rhodotorula mucilaginosa & $Y-17501$ & AF 189958 & \\
\hline Rhodotorula mucilaginosa & CBS 8383 & AF189959 & \\
\hline Rhodotorula rubrat & $\mathrm{CBS} 17^{\mathrm{T}}$ & AF 189960 & \\
\hline Sporobolomyces alborubescenst & CBS $482^{\mathrm{T}}$ & AF189961 & \\
\hline Rhodotorula muscorum & CBS $6921^{\mathrm{T}}$ & AF070433 & \\
\hline Rhodotorula nothophagi & CBS $8166^{\mathrm{T}}$ & AF 189950 & \\
\hline Rhodotorula pallida & CBS $320^{\mathrm{T}}$ & AF189962 & \\
\hline Rhodotorula philyla & CBS $6272^{\mathrm{T}}$ & AF075471 & \\
\hline Rhodotorula pilati & CBS $7039^{\mathrm{T}}$ & AF189963 & \\
\hline
\end{tabular}


J. W. Fell and others

Table 2 (cont.)

\begin{tabular}{|c|c|c|c|}
\hline \multirow[t]{2}{*}{ Strain } & \multirow[t]{2}{*}{ Strain no.* } & \multicolumn{2}{|c|}{ GenBank accession no. } \\
\hline & & D1/D2 & ITS $\dagger$ \\
\hline Rhodotorula pustula & CBS $6527^{\mathrm{T}}$ & AF189964 & \\
\hline Rhodotorula slooffiae & CBS $5706^{\mathrm{T}}$ & AF189965 & \\
\hline Rhodotorula slooffiae & CBS 7093 & AF189966 & \\
\hline Rhodotorula slooffiae & CBS 7095 & AF189967 & \\
\hline Rhodotorula slooffiae & IGC 4887 & AF189968 & \\
\hline Rhodotorula sonckii & CBS $6713^{\mathrm{T}}$ & AF189969 & \\
\hline Rhodotorula vanillica & CBS $7404^{\mathrm{T}}$ & AF189970 & \\
\hline Rhodotorula yarrowii & CBS $7417^{\mathrm{T}}$ & AF189971 & \\
\hline Sakaguchia dacryoidea & CBS $6353^{\mathrm{T}}$ & AF189972 & \\
\hline Sakaguchia dacryoidea & CBS 6356 & AF189973 & \\
\hline Sphacelotheca polygoni-persicariae & IGC 4293 & AF189974 & \\
\hline Sporidiobolus microsporus & CBS $7041^{\mathrm{T}}$ & AF070436 & \\
\hline Sporidiobolus johnsonii & CBS $5470^{\mathrm{T}}$ & AF070435 & \\
\hline Sporidiobolus johnsonii & CBS 2630 & AF189976 & \\
\hline Sporobolomyces holsaticust & CBS $1522^{\mathrm{T}}$ & AF189975 & \\
\hline Sporidiobolus pararoseus & CBS $491^{\mathrm{T}}$ & AF189977 & \\
\hline Sporobolomyces ruber & CBS $4216^{\mathrm{T}}$ & AF189978 & \\
\hline Sporobolomyces pararoseus & CBS $484^{\mathrm{T}}$ & AF070437 & \\
\hline Sporidiobolus ruineniae & CBS $5001^{\mathrm{T}}$ & AF070438 & \\
\hline Sporidiobolus ruineniae var. coprophilus & CBS $5811^{\mathrm{T}}$ & AF070434 & \\
\hline Sporidiobolus salmonicolor & CBS $490^{T}$ & AF070439 & \\
\hline Sporidiobolus salmonicolor & Y-17498 & AF189979 & \\
\hline Sporobolomyces coprosmae & CBS $7899^{\mathrm{T}}$ & AF189980 & \\
\hline Sporobolomyces coprosmicola & CBS $7897^{\mathrm{T}}$ & AF189981 & \\
\hline Sporobolomyces dracophylli & CBS $7900^{\mathrm{T}}$ & AF189982 & \\
\hline Sporobolomyces elongatus & CBS $8080^{\mathrm{T}}$ & AF189983 & \\
\hline Sporobolomyces falcatus & CBS $7368^{\mathrm{T}}$ & AF075490 & \\
\hline Sporobolomyces foliicola & CBS $8075^{\mathrm{T}}$ & AF189984 & \\
\hline Sporobolomyces gracilis & CBS $71^{\mathrm{T}}$ & AF189985 & \\
\hline Sporobolomyces griseoflavus & CBS $7284^{\mathrm{T}}$ & AF189986 & \\
\hline Sporobolomyces inositophilus & CBS $7310^{\mathrm{T}}$ & AF189987 & \\
\hline Sporobolomyces kluyveri-nielii & CBS $7168^{\mathrm{T}}$ & AF189988 & \\
\hline Sporobolomyces lactophilus & CBS $7527^{\mathrm{T}}$ & AF177411 & \\
\hline Sporobolomyces linderae & CBS $7893^{\mathrm{T}}$ & AF189989 & \\
\hline Sporobolomyces marcillae & CBS $4217^{\mathrm{T}}$ & AF070440 & \\
\hline Sporobolomyces oryzicola & CBS $7228^{\mathrm{T}}$ & AF189990 & \\
\hline Sporobolomyces phyllomatis & CBS $7198^{\mathrm{T}}$ & AF189991 & \\
\hline Sporobolomyces roseus & CBS $486^{\mathrm{T}}$ & AF070441 & \\
\hline Sporobolomyces ruber & CBS $7512^{\mathrm{T}}$ & AF189992 & \\
\hline Sporobolomyces ruberrimus & CBS $7500^{\mathrm{A}}$ & AF070442 & \\
\hline Sporobolomyces ruberrimus var. albus $\ddagger$ & CBS $7501^{\mathrm{A}}$ & AF189993 & \\
\hline Sporobolomyces ruberrimus var. albus & CBS 7253 & AF189994 & \\
\hline Sporobolomyces salicinus & CBS $6983^{\mathrm{T}}$ & AF189995 & \\
\hline Sporobolomyces sasicola & CBS $7285^{\mathrm{T}}$ & AF177412 & \\
\hline Sporobolomyces singularis & CBS $5109^{\mathrm{T}}$ & AF189996 & \\
\hline Sporobolomyces subbrunneus & CBS $7196^{\mathrm{T}}$ & AF189997 & \\
\hline Sporobolomyces taupoensis & CBS $7898^{\mathrm{T}}$ & AF 177413 & \\
\hline Sporobolomyces tsugae & CBS $5038^{\mathrm{T}}$ & AF189998 & \\
\hline Sporobolomyces xanthus & CBS $7513^{\mathrm{T}}$ & AF177414 & \\
\hline Sterigmatomyces elviae & CBS $5922^{\mathrm{T}}$ & AF177415 & \\
\hline
\end{tabular}


Table 2 (cont.)

\begin{tabular}{|c|c|c|c|}
\hline \multirow[t]{2}{*}{ Strain } & \multirow[t]{2}{*}{ Strain no.* } & \multicolumn{2}{|c|}{ GenBank accession no. } \\
\hline & & D1/D2 & ITS $\dagger$ \\
\hline Rhodotorula acutat & CBS $7053^{\mathrm{T}}$ & AF189999 & \\
\hline Rhodotorula dulciaminist & CBS $7288^{\mathrm{T}}$ & AF190000 & \\
\hline Sterigmatomyces halophilus & CBS $4609^{\mathrm{T}}$ & AF177416 & \\
\hline
\end{tabular}

* T, Type strain; A, authentic strain.

$\dagger$ Not all strains were examined in the ITS region.

$\ddagger$ Species considered to be synonyms of the lead listed species as determined by sequence analysis and examination of classical taxonomic characteristics.

Table 3. Ustilaginomycetous yeasts examined in the D1/D2 rDNA regions

\begin{tabular}{|c|c|c|}
\hline Strain & Strain no.* & Accession no. \\
\hline Malassezia furfur & CBS $7019^{\mathrm{T}}$ & AJ249955† \\
\hline Malassezia globosa & CBS $7966^{\mathrm{T}}$ & $\mathrm{AJ} 249951 \dagger$ \\
\hline Malassezia obtusa & CBS $7876^{\mathrm{T}}$ & AJ249954† \\
\hline Malassezia pachydermitis & CBS $1879^{\mathrm{T}}$ & AJ249952† \\
\hline Malassezia restricta & CBS $7877^{\mathrm{T}}$ & $\mathrm{AJ} 249950 \dagger$ \\
\hline Malassezia slooffiae & CBS $7956^{\mathrm{T}}$ & $\mathrm{AJ} 249956 \dagger$ \\
\hline Malassezia sympodialis & CBS $7222^{\mathrm{T}}$ & AJ249953† \\
\hline Rhodotorula acheniorum & CBS $6386^{\mathrm{T}}$ & AF190001 \\
\hline Rhodotorula bacarum & CBS $6526^{\mathrm{T}}$ & AF190002 \\
\hline Rhodotorula hinnulea & CBS $8079^{\mathrm{T}}$ & AF190003 \\
\hline Rhodotorula phylloplana & CBS $8073^{\mathrm{T}}$ & AF190004 \\
\hline Sympodiomycopsis paphiopedili & CBS $7429^{\mathrm{T}}$ & AF190005 \\
\hline
\end{tabular}

* T, Type strain.

$\dagger$ EMBL accession number.

are denoted by a ' $T$ ' following the strain number. The GenBank numbers for D1/D2 and ITS are listed in Tables 1-3. Not all strains were analysed in the ITS region. Sequences not included in the lists that are illustrated in Figs 1-3 were from the following sources: Tremella (Chen, 1998), smut and related fungi (Begerow et al., 1997), Entyloma, Melanotaenium, Pseudozyma, Tilletiopsis, Tilletiaria and Ustilago spp. (Boekhout et al., 1995).

Strains were obtained from the American Type Culture Collection (ATCC), ARS Culture Collection (NRRL), Peoria, IL (Y), Centraalbureau voor Schimmelcultures (CBS), the Portuguese Yeast Culture Collection (New University of Lisbon) (IGC), Brian Steffenson, North Dakota State University (KB) and Helen Vishniac, Oklahoma State University (Cryptococcus consortionis). Cells from pure cultures were grown for 12-24 h in GYP broth $(2 \%$ glucose, $0.5 \%$ peptone and $0 \cdot 1 \%$ yeast extract), then centrifuged/washed with distilled water and converted to sphaeroplasts by incubation for $2 \mathrm{~h}$ at $37^{\circ} \mathrm{C}$ in $10 \mathrm{mM}$ citrate buffer, $\mathrm{pH} 5 \cdot 8,1 \mathrm{M}$ sorbitol and $10 \mathrm{mg} \mathrm{ml}^{-1}$ lysing enzymes from Trichoderma harzianum (Sigma), which was freshly prepared for each procedure. DNA was extracted and purified from the sphaeroplasts using a QIAamp tissue culture kit (Qiagen) according to the standard protocol. The
DNA was amplified with the universal fungal primers ITS 5 (5'-GGA AGT AAA AGT CGT AAC AAG G-3') and LR6 (5'-CGC CAG TTC TGC TTA CC-3') using thermal cyclers (MJ Research). The resulting amplicon was purified with the QIAquick PCR purification kit (Qiagen).

Cycle sequencing of the D1/D2 600-650 bp region at the 5' end of the LrDNA employed forward primer F63 (5'-GCA TAT CAA TAA GCG GAG GAA AAG-3') and reverse primer LR3 (5'-GGT CCG TGT TTC AAG ACG G-3'). ITS cycle sequencing primers included forward-strand primer ITS1 (5'-TCC GTA GGT GAA CCT GCG G-3') and reverse-strand primer ITS4 $\left(5^{\prime}\right.$ TCC TCC GCT TAT TGA TAT GC-3'). Nucleotide sequences were obtained using the standard Li-Cor protocol with IRD800 conjugate primers and a Li-Cor automated sequencer. All strains were examined with these techniques at the University of Miami; exceptions included strains of Malassezia that were sequenced at CBS using an ABI sequencer and protocol. Sequences were aligned with MEGALIGN (DNAstar) and visually corrected. Phylogenetic analysis employed PAUP* 4.0 using parsimony analysis, random step-wise addition and tree bisection-reconnection. Complete sequences are available in GenBank (Tables 1-3).

\section{RESULTS AND DISCUSSION}

Basidiomycetous yeasts are characterized by electrondense and layered cell walls (Kreger-van Rij \& Veenhuis, 1971; Simmons \& Ahearn, 1987) and septal morphology, which has been used as a primary phylogenetic character (Boekhout et al., 1998; Moore, 1998). Hyphal states of species belonging to the Urediniomycetes have septa with 'simple' pores in which the cell wall is attenuated towards the central pore. Usually a single pore is observed, but multiple pores occur in Kriegeria eriophori (McLaughlin et al., 1995). Cell wall composition in the Urediniomycetes is dominated by mannose, glucose is present, fucose and rhamnose may be present and xylose is absent (Prillinger et al., 1991). Urediniomycetous yeasts are characterized by an absence of starch-like compounds and an inability to utilize inositol. Ustilaginomycetous taxa have 'micropore-like' septa, which may or may not have an inflated margin and which differ from 'simple' pores because they do not have tapering cell walls and probably lack a true pore (Bauer et al., 1989, 


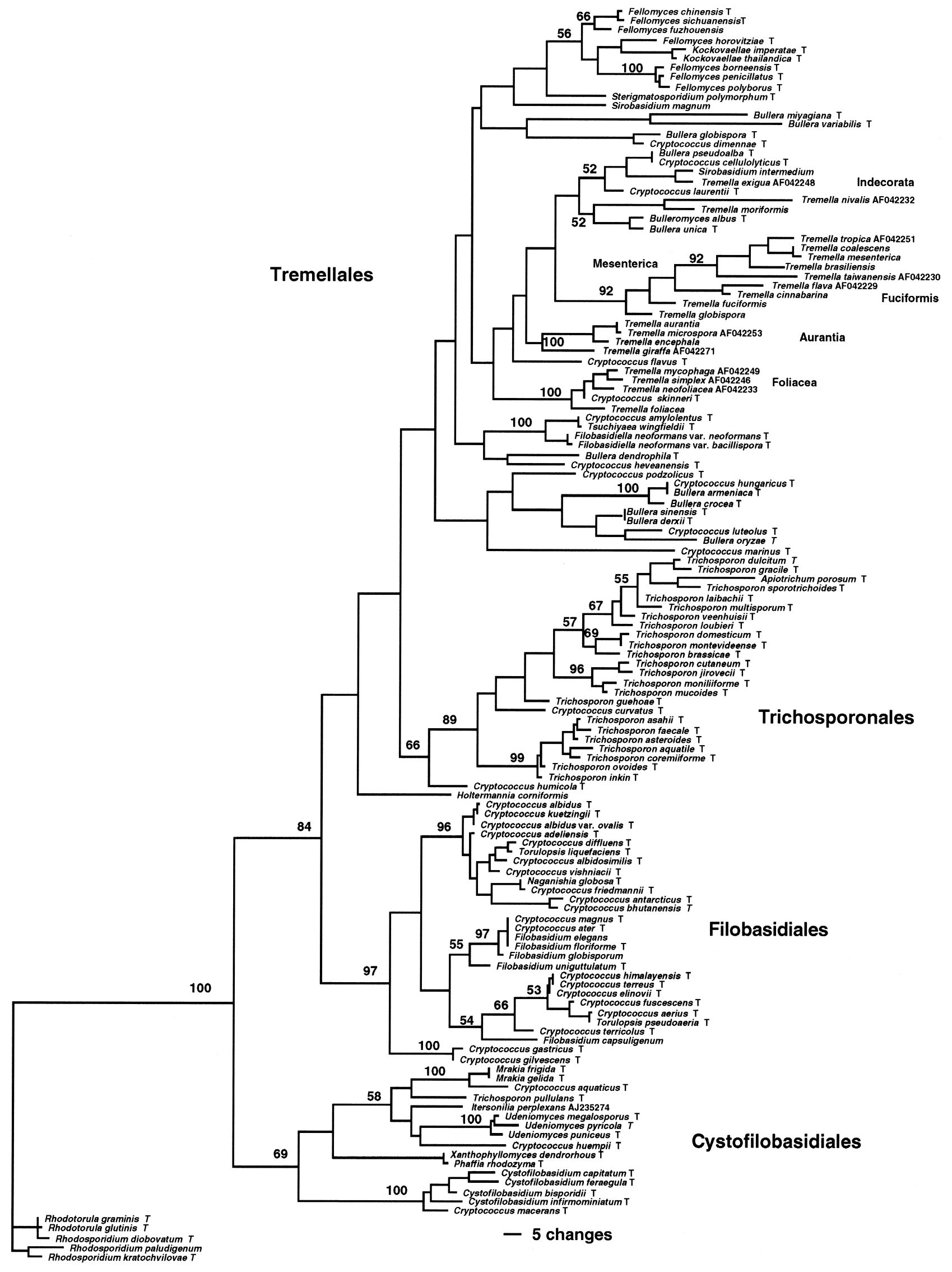

Fig. 1. For legend see facing page. 
1997; Boekhout et al., 1992, 1998; O'Donnell \& McLaughlin, 1984). The ustilaginomycetous yeast cell walls contain dominant levels of glucose, galactose and mannose are present and xylose is absent (Prillinger et al., 1990). Inositol may or may not be utilized; starch-like compounds are not produced. The hymenomycetous yeasts, in contrast, have dolipore septa and the cell walls contain glucose, mannose and xylose (Prillinger et al., 1991, 1993; Roeijmans et al., 1998; Weijman \& Golubev, 1987). Inositol is usually assimilated and starch-like compounds are produced by a majority of the hymenomycetous yeasts. Our molecular studies confirm the phylogenetic principles developed with the small-subunit rDNA (Swan \& Taylor, 1995a, b, c; Swann et al., 1999) that yeasts are distributed among three classes. Consequently, our data are presented in trees that represent yeasts associated with the Hymenomycetes (Fig. 1), the Urediniomycetes (Fig. 2) and the Ustilaginomycetes (Fig. 3).

\section{Yeast species of the Tremellomycetidae of the Hymenomycetes}

On the basis of sequence analysis of the small-subunit rDNA, Swann \& Taylor (1995c) recommended two subclasses among the Hymenomycetes: (1) the Hymenomycetidae, containing the non-yeast-like macrofungi, including the mushrooms and puffballs; and (2) the Tremellomycetidae. As a result of our analysis of the D1/D2 region, the hymenomycetous yeasts are presented in four major clades of the Tremellomycetidae (Fig. 1): the Tremellales, the Trichosporonales, the Filobasidiales and the Cystofilobasidiales. The hymenomycetous yeast genus, Cryptococcus, is polyphyletic and occurs in all four clades. The remaining genera occur in single clades: (1) the Tremellales - Bullera, Bulleromyces, Fellomyces, Filobasidiella, Kockovaella and Tsuchiyaea; (2) the Trichosporonales - all species of Trichosporon with the exception of Trichosporon pullulans, which occurs in the Cystofilobasidiales; (3) the Filobasidiales Filobasidium; and (4) the Cystofilobasidiales - Cystofilobasidium, Mrakia, Phaffia, Udeniomyces and Xanthophyllomyces.

\section{The Tremellales clade}

The Tremellales consists of seven families (Wells, 1994) but the molecular systematics of this order has not been established. Our study concentrated on the occurrence of yeasts in this order. In addition, we included species of the Tremellaceae (Tremella spp. and Holtermannia corniformis) and two species of the Sirobasidiaceae (Sirobasidium magnum and Siro- basidium intermedium). The Tremellales clade and many of the internal clusters do not have bootstrap support, which may reflect the heterogeneity of the order and/or the incomplete sampling of taxa. The major teleomorphic representative of the Tremellales included in this analysis is the genus Tremella. Our view of Tremella is preliminary, as the analysis covers only 20 of the estimated 120 species (Bandoni, 1995). Chen (1998) demonstrated five clusters among the species of Tremella, which are indicated in Fig. 1. Cryptococcus skinneri is in the Foliacea cluster, which has strong $(100 \%)$ statistical support. The Indecorata cluster that lacks statistical support includes Bulleromyces albus, Bullera unica, Bullera pseudoalba, Cryptococcus cellulolyticus and Cryptococcus laurentii.

There are two distinct teleomorphic yeast genera in the Tremellales, namely Bulleromyces and Filobasidiella. A third genus, Sterigmatosporidium, has been described as a teleomorph; however, the apparent absence of a tremellaceous basidium suggests that a further investigation of the life cycle is required. The 2-4-celled basidial morphology of Bulleromyces is similar to that of many of the Tremellales (Boekhout et al., 1991). The anamorph of Bulleromyces is in the genus Bullera (Boekhout \& Nakase, 1998), which only occurs in the Tremellales. Based on distributions of species within the Tremellales, many of the Cryptococcus species appear to be related to Bullera spp., for example Bullera pseudoalba/C. cellulolyticus and Bullera armeniaca/Cryptococcus hungaricus. A major taxonomic distinction between Bullera and Cryptococcus is the production of ballistoconidia by Bullera, which, based on these relationships, does not appear to be a phylogenetically significant character. A similar conclusion can be reached for the cluster of stalked-conidia-forming genera Kockovaella and Fellomyces, which differ by the presence or absence of ballistoconidia.

In contrast to previous concepts, which placed Filobasidiella among the Filobasidiales (Bandoni, 1995; Boekhout et al., 1998), the human pathogens Filobasidiella neoformans var. neoformans and var. bacillispora form a statistically supported (100\%) cluster within the Tremellales. The sexual cycle of this species is distinct from the typical tremellaceous yeasts because of the presence of a slender, cylindrical, capitate holobasidium with basipetally formed chains of basidiospores (Kwon-Chung, 1998).

\section{The Trichosporonales clade}

The Trichosporonales clade (with bootstrap support of $89 \%$ ) contains all of the species of Trichosporon, except for Trichosporon pullulans, which is located

Fig. 1. Hymenomycetous yeasts: phylogenetic analysis of the D1/D2 region of the large-subunit rDNA (one of 100 equally parsimonious trees). Number of characters, 651; constant characters, 285; parsimony-uninformative characters, 71; parsimony-informative characters, 295. Tree length, 2163; consistency index, 0.2779; homoplasy index, 0.7721. Numbers on branches, bootstrap percentages from 100 full heuristic bootstrap replications. The Tremellales cluster names are from Chen (1998). Species with GenBank numbers represent sequences obtained from GenBank; see Table 1 for the GenBank numbers of strains sequenced for this study. T, Type strain. 


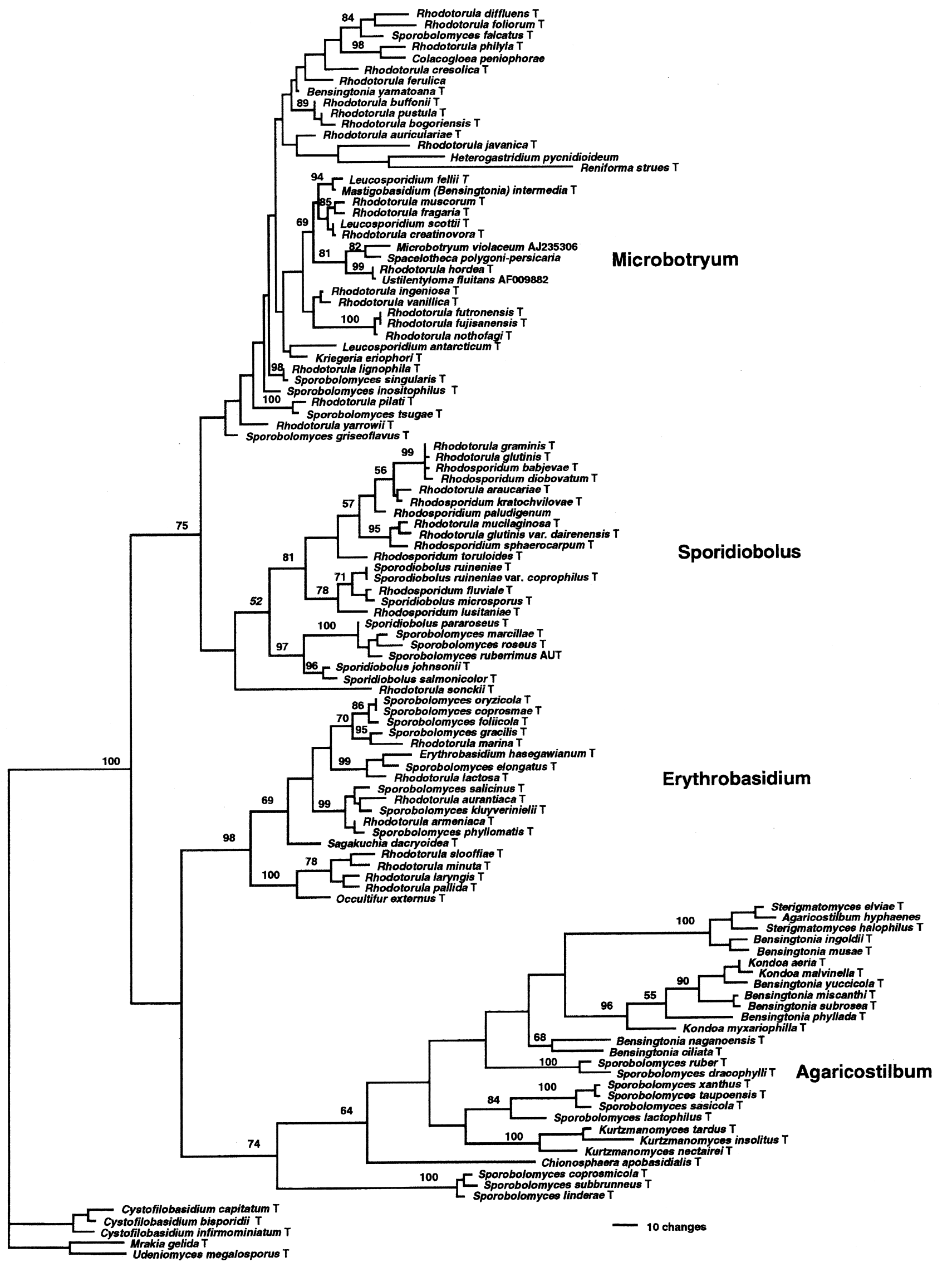

Fig. 2. For legend see facing page. 
among the Cystofilobasidiales. The genus Trichosporon, which is characterized by the presence of arthroconidia, has been studied in detail by Guého et al. $(1992,1993)$ and includes the medically important species Trichosporon asahii, Trichosporon cutaneum, Trichosporon inkin and Trichosporon mucoides. Two additional species (C. curvatus and Apiotrichum porosum) that do not produce arthroconidia are found in this clade. The strain of $A$. porosum that we examined produced extensive hyphae and lacked a yeast-like phase. Cryptococcus curvatus produces pseudohyphae and yeast cells that range in shape from ovoid to elongate. A third species, Cryptococcus humicola, is attached to the clade $(66 \%$ bootstrap support). This species, which has a distinct yeast phase, produces extensive pseudo and true mycelium; arthroconidia, however, have not been observed. Further investigations on these Cryptococcus spp. and $A$. porosum are required to develop an understanding of their phylogenetic relationships to the genus Trichosporon.

The morphological and molecular characteristics of the genus Trichosporon demonstrate that the clade is phylogenetically distinct from the hymenomycetous sister clades Tremellales, Filobasidiales and Cystofilobasidiales. Consequently, the new order Trichosporonales is proposed.

Trichosporonales Boekhout et Fell ord. nov. Fungi hymenomycetales vel levadiniformes, anamorphici. Hyphae verae plerumque modo arthroconidiorum fragmentatae. Septa plerumque doliporis perforata; parenthesomatibus vulgo structuris tubularibus vel vesicularibus instructa. Parietes xylosum continentes. Coenzyma $\mathrm{Q}_{9}$ vel $\mathrm{Q}_{10}$.

Typus: Trichosporon Behrend. Anamorphic, hymenomycetous yeasts or yeast-like fungi. True hyphae proliferating by arthroconidia. Septa with dolipores, which may or may not have tubular/vesicular parenthesomes; cell walls with xylose; coenzyme $\mathrm{Q}_{9}$ or $\mathrm{Q}_{10}$. Type: Trichosporon Behrend. This order, which forms a coherent clade (with $89 \%$ bootstrap support), is a sister group of the Tremellales. Species included are: Trichosporon asahii, Trichosporon asteroides, Trichosporon aquatile, Trichosporon brassicae, Trichosporon coremiiforme, Trichosporon cutaneum, Trichosporon domesticum, Trichosporon dulcitum, Trichosporon faecale, Trichosporon gracile, Trichosporon guehoiae, Trichosporon inkin, Trichosporon jirovecii, Trichosporon laibachii, Trichosporon loubieri, Trichosporon moniliiforme, Trichosporon montevideense, Trichosporon mucoides, Trichosporon multisporum, Tricho- sporon ovoides, Trichosporon veenhuisii, Apiotrichum porosum, Cryptococcus curvatus and possibly Cryptococcus humicola. rDNA sequences indicate that Trichosporon pullulans belongs to the Cystofilobasidiales (Fell et al., 1999).

\section{The Filobasidiales clade}

The order Filobasidiales originally included the genera Cystofilobasidium, Filobasidiella, Filobasidium, Mrakia and Xanthophyllomyces (Bandoni, 1995; Boekhout et al., 1998; Wells, 1994). Swann \& Taylor (1995c) recommended a reassessment of the Filobasidiales, indicating that Filobasidiella was more closely related to Tremella than to Filobasidium; in addition, Cystofilobasidium and Mrakia did not form a monophyletic group with Filobasidium. The data presented in Fig. 1 concur with the Swann \& Taylor conclusions. The Filobasidiales clade has bootstrap support of $97 \%$. The only teleomorphic genus in this clade is Filobasidium, whose sexual cycle differs from that of Filobasidiella by the formation of petal-like whorls of basidiospores at the apex of a slender holobasidium (Kwon-Chung, 1998). The Filobasidiales clade is composed of four clusters, though they do not all have strong bootstrap support. One cluster includes Cryptococcus albidus and related species, as well as several Antarctic species (Cryptococcus albidosimilis, Cryptococcus antarcticus, Cryptococcus friedmannii and Cryptococcus vishniacii). The second cluster consists of Cryptococcus ater and the members of Filobasidium, with the exception of Filobasidium capsuligenum (which is found in the third cluster with Cryptococcus aerius, Cryptococcus terreus and related species). The fourth cluster consists of Cryptococcus gastricus and Cryptococcus gilvescens. The necessary emendation of the order Filobasidiales is premature, as members of the family Syzygosporaceae were not analysed.

\section{The Cystofilobasidiales clade}

The recently described order Cystofilobasidiales (Fell et al., 1999) has teliospores, which is a unique feature among the teleomorphic Hymenomycetes. Generally, this type of probasidium is found among the urediniomycetous yeasts. Other major characteristics of the Cystofilobasidiales include holobasidia and hyphal septa with dolipores that lack parenthesomes. The teliospore-forming genera Mrakia and Cystofilobasidium are located in two distinct clusters. Anamorphic genera include the ballistoconidiaforming Udeniomyces, the arthroconidia-forming $T$. pullulans and several species of Cryptococcus. Xantho-

Fig. 2. Urediniomycetous yeasts, representing four clades (Microbotryum, Sporidiobolus, Erythrobasidium and Agaricostilbum): phylogenetic analysis of the D1/D2 region of the large-subunit rDNA (one of 100 equally parsimonious trees). Number of characters, 657; constant characters, 241; parsimony-uninformative characters, 56; parsimonyinformative characters, 360. Tree length, 2402; consistency index, 0.3118; homoplasy index, 0.6882 . Numbers on branches, bootstrap percentages from 100 full heuristic bootstrap replications. Species with GenBank numbers represent sequences obtained from GenBank; see Table 2 for the GenBank numbers of strains sequenced for this study. T, Type strain. 


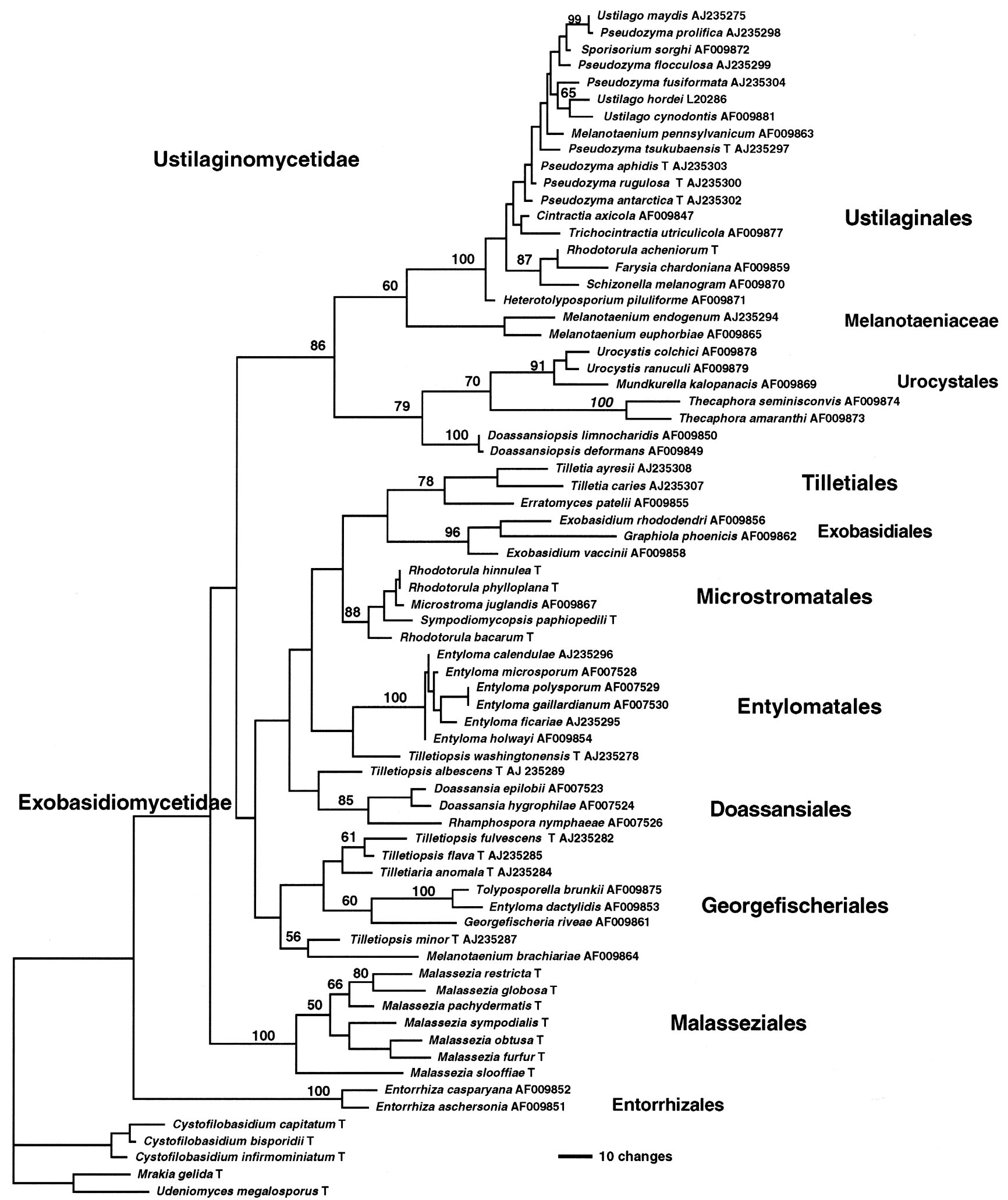

Fig. 3. Ustilaginomycetous fungi and associated yeasts: phylogenetic analysis of the D1/D2 region of the large-subunit rDNA (one of 100 equally parsimonious trees). Number of characters, 540; constant characters, 218; parsimonyuninformative characters, 37; parsimony-informative characters, 285. Tree length, 1555; consistency index, 0.3588; homoplasy index, 0.6412. Numbers on branches, bootstrap percentages from 100 full heuristic bootstrap replications. Names of orders are from Begerow et al. (1997). Species with GenBank numbers represent sequences obtained from GenBank; see Table 3 for the GenBank numbers of strains sequenced for this study. T, Type strain. 
phyllomyces dendrorhous and Phaffia rhodozyma are important agro-industrial sources of astaxanthin. On the basis of sequence analysis of the intergenic spacer (IGS) and ITS regions, these two taxa have been reported to represent separate species (Fell \& Blatt, 1999). The teleomorph (Xanthophyllomyces) produces holobasidia that do not arise from teliospores.

\section{Yeast species of the Urediniomycetes}

There are four major clades in this tree (Fig. 2), which are labelled for this discussion as the clades Microbotryum, Sporidiobolus, Agaricostilbum and Erythrobasidium. Three genera are in two or more clades. Bensingtonia occurs in the Microbotryum and Agaricostilbum clades; Rhodotorula is in the Microbotryum, Sporidiobolus and Erythrobasidium clades, but not the Agaricostilbum clade; Sporobolomyces is in all four clades. Genera that occur in single clades areas follows: (1) Microbotryum clade - Leucosporidium; (2) Sporidiobolus clade-Rhodosporidium and Sporidiobolus; (3) Agaricostilbum clade - Kondoa, Kurtzmanomyces and Sterigmatomyces; (4) Erythrobasidium cladeErythrobasidium, Sakaguchia and Occultifur.

\section{The Microbotryum clade}

The Microbotryum and Sporidiobolus clades represent the Sporidiobolaceae of Boekhout et al. (1998) and the Microbotryomycetidae of Swann et al. (1999). The order Microbotryales was formally described by Bauer et al. (1997) as " phytoparasitic members of the Basidiomycota having transversely septate basidia with multiple production of sessile basidiospores and only intercellular hyphae.' These authors divided the order into two families, i.e. the Microbotryaceae (with poreless septae) and the Ustilentylomataceae (with simple septal pores). The two families occur in a single cluster, represented by Microbotryum violaceum and Ustilentyloma fluitans, with $81 \%$ bootstrap support (Fig. 2 ). In addition to members of the Microbotryales, this clade includes species from two other orders: Colacogloea peniophorae and Kriegeria eriophori in the Platygoleales; and Heterogastridium pycnidioideum in the Heterogastridiales (Bandoni, 1995). Consequently, the Microbotryum clade is phylogenetically diverse, as reflected by the lack of bootstrap support for the clade and for many of the internal clusters. A unifying characteristic within this clade is the presence of colacosomes or lenticular bodies, which are an indication of mycoparasitism (Bauer \& Oberwinkler, 1991; Bauer et al., 1997; Boekhout et al., 1992).

Yeast species from six genera are included in the Microbotryum clade: the teliospore-forming genera Leucosporidium and Mastigobasidium and species of the anamorphic genera Rhodotorula, Sporobolomyces, Bensingtonia and Reniforma. Golubev (1999) described Mastigobasidium, which is the sexual state of Bensingtonia intermedia. The latter species is the sole member of Bensingtonia that resides in the Micro- botryum clade. Mastigobasidium intermedium is closely related to Leucosporidium fellii and the two species produce phragmometabasidia with bacilliform basidiospores that form in clusters on pegs (StatzellTallman \& Fell, 1998; Golubev, 1999). This cluster characteristic is unique among the teliosporic yeasts, which usually produce single basidiospores or pairs of basidiospores per sporulation site. The formation of phragmometabasidia by Leucosporidium and Mastigobasidium is a characteristic shared with the teliosporeforming plant parasites Microbotryum, Sphacelotheca and Kriegeria.

The majority of the yeasts in the Microbotryum clade produce white- to cream-coloured colonies, in contrast to the visible red pigments produced by species among the Sporidiobolus clade. An exception is Rhodotorula fujisanensis, whose colonies may have a light pink colour (Johnson \& Phaff, 1978; Sampaio \& Fonseca, 1995). Reniforma strues is unique among the basidiomycetous yeasts because of the presence of kidneyshaped vegetative cells and coenzyme $Q_{7}(H . J$. Roeijmans, personal communication); other yeasts in the Microbotryomycetidae contain coenzyme $\mathrm{Q}_{9}$ or $\mathrm{Q}_{10}$. The specific placement of Reniforma strues within the clade is questionable, as the apparent proximity to $H$. pycnidioideum may be a result of long-branch attraction in the parsimony analysis rather than a phylogenetic relationship.

\section{The Sporidiobolus clade}

The Sporidiobolus clade represents the red-pigmented teliosporic yeasts Rhodosporidium and Sporidiobolus with phragmometabasidia, and their related anamorphs in the genera Rhodotorula and Sporobolomyces. Although pigment chemistry is usually considered to be an unreliable characteristic in systematics, the presence of carotenoid pigments appears to differentiate the Sporidiobolus and Microbotryales clades. Species in the Sporidiobolus clade do not produce extracellular starch-like compounds or utilize D-glucuronate; coenzyme $\mathrm{Q}_{10}$ is usually present. In this clade, there are two major clusters with significant statistical support: the Rhodotorula graminis cluster (81\% support) and the Sporidiobolus pararoseus cluster ( $98 \%$ support). The Rhodotorula graminis cluster consists of two branches: (1) the non-ballistoconidial species of Rhodotorula and Rhodosporidium; and (2) the Sporidiobolus ruineniae branch that includes the ballistoconidia-positive (Sporidiobolus) and -negative (Rhodosporidium) species. The unique characteristic of species in this branch, in contrast to other members of the Sporidiobolus clade, is the formation of phragmometabasidia on pronounced stalks. Species in the Sporidiobolus pararoseus cluster produce ballistoconidia and develop phragmometabasidia that lack stalked connections to the teliospore.

The species composition of the Sporidiobolus clade (Fig. 2) conforms with the core species of the Sporidiales as presented by Swann \& Taylor (1995b), 
with the exception of Leucosporidium scottii and $H$. pycnidioideum, which are recognized (Fig. 2) as members of the Microbotryum clade. Moore (1980) distinguished two families in his concept of the Sporidiales: the Sporidiaceae and the Sporidiobolaceae, which are characterized by presence or absence of ballistoconidia. We do not accept these families, because of the close relationship between ballistoconidia-forming and non-ballistoconidiaforming species (as exemplified by the branch arrangements of Rhodosporidium fluviale/Sporidiobolus microsporus and Rhodosporidium lusitaniae/Sporidiobolus ruineniae). The biological uniformity of the Sporidiobolus clade indicates that this group should be formally recognized as an order. However, the weak (52\%) statistical support suggests the need for further investigation with additional taxa.

\section{The Erythrobasidium clade}

The Erythrobasidium clade, as coined by Swann \& Taylor (1955a), is strongly supported $(98 \%)$ with four significant internal clusters. This clade includes pigmented species of Rhodotorula, Sporobolomyces, Sakaguchia, Erythrobasidium and Occultifur. Sexual cycles within the clade differ. Sakaguchia (Rhodosporidium) dacryoideum produces teliospores that germinate to a 2-4-celled metabasidium with repetitively budding basidiospores. Erythrobasidium produces holobasidia directly from dikaryotic hyphae. Occultifur externus (Sampaio et al., 1999) is a nonteliospore-forming yeast that produces auricularioid basidia with ballistospores. The strong statistical support indicates that further biological study will develop criteria for formal classification of the clade.

\section{The Agaricostilbum clade}

The Agaricostilbum clade is comprised of several strongly supported clusters, which demonstrate some generic and phenotypic separation. The clade is largely composed of ballistoconidia-forming species of the genera Bensingtonia and Sporobolomyces. The several branches that include Bensingtonia, Sterigmatomyces and Kondoa have the unified characteristic of coenzyme $\mathrm{Q}_{9}$, in contrast to the Sporobolomyces, Kurtzmanomyces branches that exhibit the presence of coenzyme $\mathrm{Q}_{10}$.

There is morphological variability within the Agaricostilbum clade. Species in the genus Agaricostilbum inhabit palms and produce synnemata-like basidiomata. Chionosphaera apobasidialis, which occurs on a long branch in the Agaricostilbum clade, produces a basidiocarp that is terminally located on synnemata composed of dikaryotic hyphae. Kondoa was originally described with teliospores, but an evaluation of the life cycle of Kondoa revealed the formation of auricularoid basidia with ballistospores in the absence of teliospore production (Fonseca et al., 2000a). Sterigmatomyces is an anamorphic genus in the same cluster with Agaricostilbum hyphaenes (bootstrap support of $100 \%$ ). The yeast cells of Sterigmatomyces form distinct stalks with terminal conidia and a midstalk conidial separation. Kurtzmanomyces is similar to Sterigmatomyces in terms of the formation of conidia on stalks; however, conidial separation in Kurtzmanomyces is at the distal end of the stalk. In addition, some of the Sporobolomyces species in this cluster (particularly Sporobolomyces lactophilus) can reproduce sympodially with conidia on a long stalk.

\section{Distribution of yeasts among the Ustilaginomycetes}

Fig. 3 consists of the D1/D2 sequences from yeast species in our study combined with data on the plant associated fungi in the Ustilaginomycetes by Begerow et al. (1997), Pseudozyma, Tilletia and Tilletiopsis spp. by Boekhout et al. (1995). Begerow et al. (1997) separated the Ustilaginomycetes into the clades, as depicted in Fig. 3. The majority of the yeast species examined, which were originally isolated from plants, are distributed into several clades: Pseudozyma spp. and Rhodotorula acheniorum are in the Ustilaginales of the Ustilaginomycetidae. Rhodotorula bacarum, Rhodotorula hinnulea, Rhodotorula phylloplana and Sympodiomycopsis paphiopedili are in the Microstromatales of the Exobasidiomycetidae. Tilletia is phylogenetically associated with the Tilletiales. Tilletiopsis is found among the Entylomatales, Doassaniales and Georgefischeriales.

Species of Malassezia appear in a statistically supported $(100 \%)$ clade that is not included in either the Ustilaginomycetidae or the Exobasidiomycetidae. The genus is distinct among the Ustilaginomycetes due to a general association with humans and other animals and because of a growth requirement, in many of the strains, for fatty acids. Begerow et al. (1999) proposed the separate order Malasseziales. For details of the genus, see Guého et al. (1996) and Guillot \& Guého (1995).

\section{Discrimination of phenotypically similar species by sequence analysis}

Strain variation in characteristics, such as carbon- and nitrogen-utilization patterns, is a critical problem associated with identifications based on classical phenotypic characteristics. This variability has resulted in long lists of synonyms for some taxa, particularly the anamorphic species. Studies have been designed to examine the validity of these synonyms. For example, taxonomic relationships among three varieties of $C$. albidus (var. albidus var. diffluens and var. aerius) were examined by comparisons of the composition of capsular polysaccharides, serological differences, $\mathrm{G}+\mathrm{C}$ content, DNA relatedness and whole-cell protein electrophoretic patterns (Ikeda et al., 1982; Shinoda et al., 1980; Sugita et al., 1992; Vancanneyt et al., 1994; Vaughan-Martini, 1991). The resulting consensus was that the type strains of these varieties represented distinct taxa. We examined this concept by D1/D2-sequence analysis of the type 


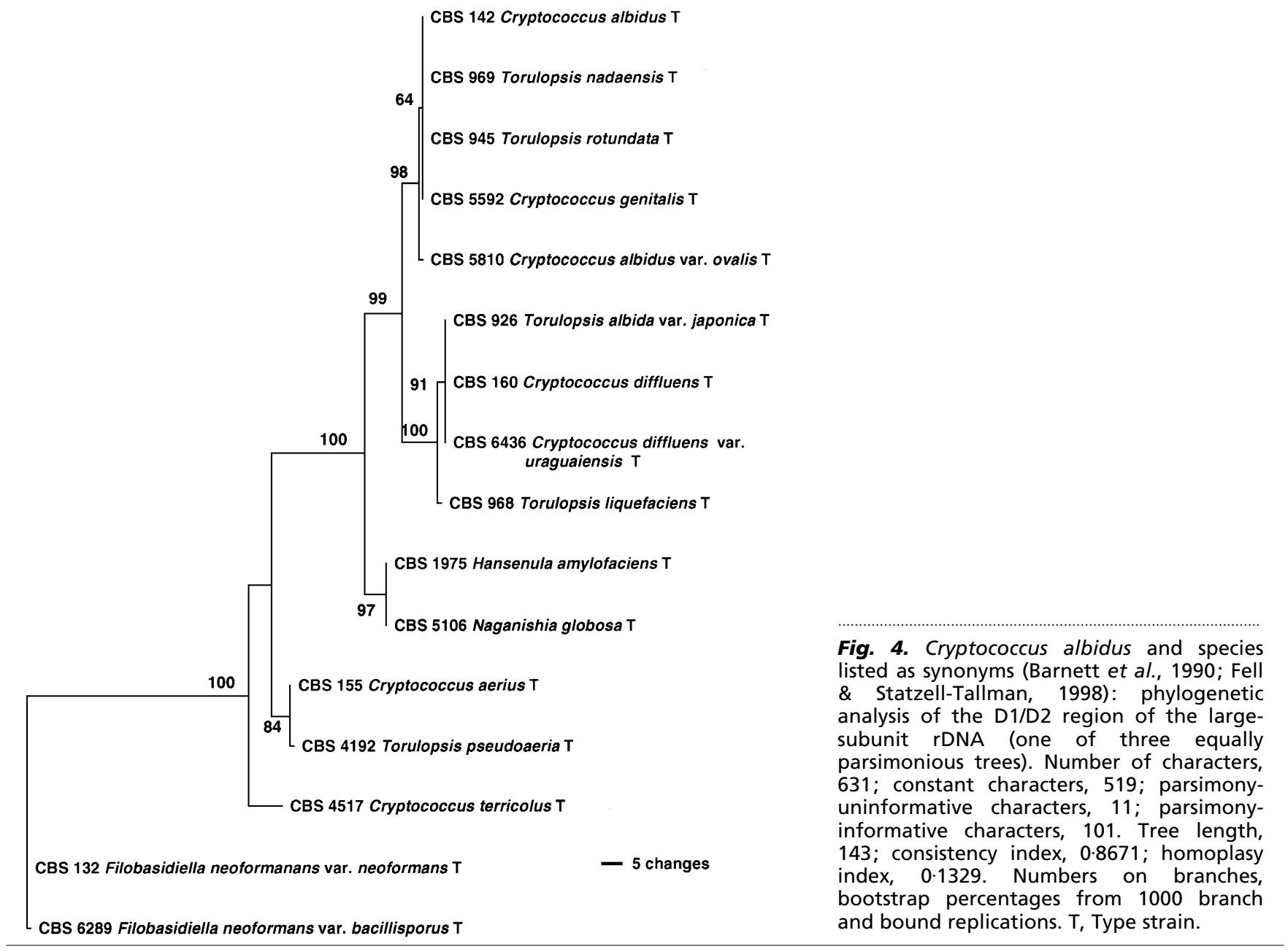

strains for 13 species listed as synonyms of $C$. albidus (Barnett et al., 1990; Fell \& Statzell-Tallman, 1998). The results (Fig. 4) indicated the presence of six distinct taxa. (1) C. albidus with three synonyms (T. nadaensis, $T$. rotundata and $C$. genitalis) and a phenotypically similar variety, i.e. C. albidus var. ovalis, which differs from $C$. albidus at one base position in the D1/D2 region and three base positions in the ITS region. These differences suggest genotypically distinct taxa or strains as observed within the genus Mrakia (Diaz \& Fell, 2000) and between strains of Xanthophyllomyces (Fell \& Blatt, 1999). (2) Cryptococcus diffluens with the synonyms Cryptococcus diffluens var. uruguaiensis and Torulopsis gelatinosa. (3) Torulopsis liquefaciens. (4) Hansenula amylofaciens and Naganishia globosa, which were originally considered to be teleomorphic ascomycetes (Dietrichson, 1954; Goto, 1963). The sequence alignment indicates that they represent an anamorphic basidiomycetous species that should be validated. (5) Cryptococcus aerius and the synonym Torulopsis pseudoaeria. (6) Cryptococcus terricolus. The taxonomic status of these species and other strains related to Cryptococcus albidus is addressed in a separate communication (Fonseca et al., 2000b).
In similar studies, Hamamoto et al. (1987) examined Rhodotorula minuta and several synonyms with DNA hybridizations: they reported high levels of relative binding of $R$. minuta with Rhodotorula texensis (65\%) and Rhodotorula tokyoensis (98\%) and low levels with Rhodotorula zsoltii (31\%), Rhodotorula pallida (24\%) and Rhodotorula marina (18\%). We examined $R$. minuta and seven synonyms (Fig. 5) and found that this complex represented five distinct species $(R$. minuta, Rhodotorula slooffiae, R. pallida, Rhodotorula laryngis and $R$. marina). R. minuta has two synonyms, namely $R$. texensis and $R$. tokyoensis. $R$. minuta differs by one nucleotide in the D1/D2 region from $R$. texensis and $R$. tokyoensis but the ITS sequences are identical, suggesting that the three strains represent a single taxon. Similarly, $R$. zsoltii is a synonym of $R$. laryngis, as the LrDNA and ITS sequences of the two taxa are identical.

\section{ITS regions for species separations}

As discussed for the C.albidus and R. minuta examples, strains with identical D1/D2 sequences are considered to represent a single species. The D1/D2 data generally 


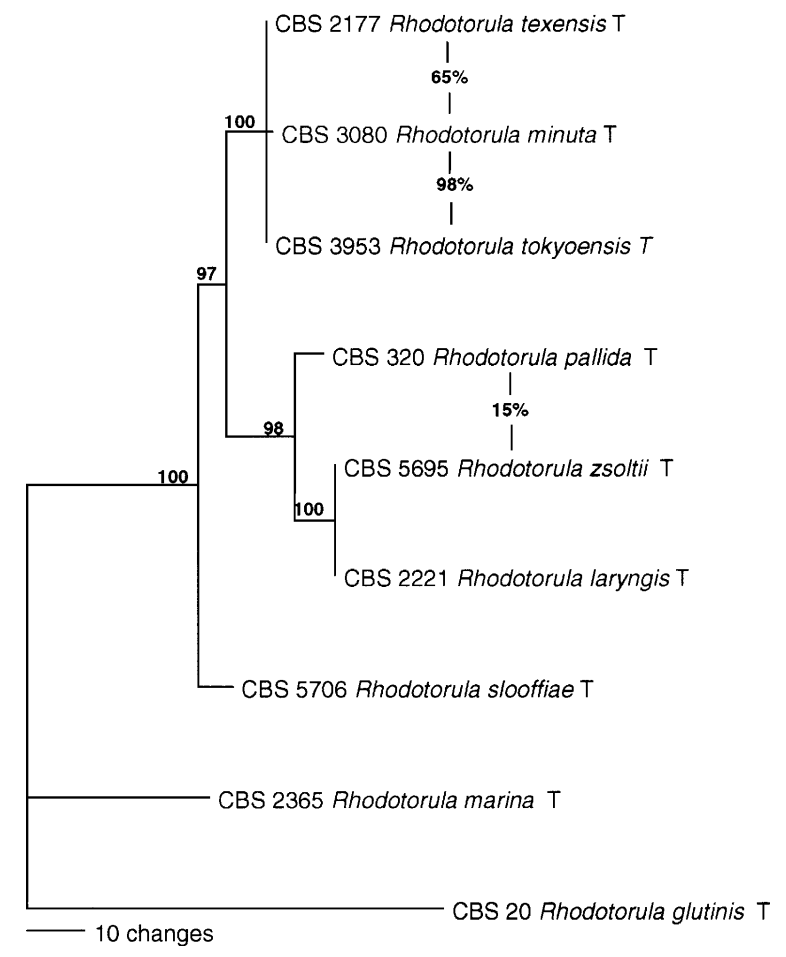

Fig. 5. Rhodotorula minuta and species listed as synonyms (Barnett et al., 1990; Fell \& Statzell-Tallman, 1998): phylogenetic analysis of the D1/D2 region of the large-subunit rDNA (single most parsimonious tree). Number of characters, 630; constant characters, 487; parsimony-uninformative characters, 89; parsimony-informative characters, 54. Tree length, 178; consistency index, 0.9101; homoplasy index, 0.0899 . Numbers on branches, bootstrap percentages from 1000 branch and bound replications. Percentages between species, DNA relatedness (\%) from Hamamoto et al. (1987). T, Type strain.

agree with available DNA hybridization results and standard phenotypic data. There are situations, however, in which mating genetics and standard phenotypic characteristics indicate that strains with identical D1/D2 sequences represent separate species. F. neoformans varieties neoformans and bacillispora (the Tremellales clade) are a case in point. Differences between the two varieties, including physiology, geographical distributions, virulence, mating incompatibility systems and molecular genetics, have been extensively studied (Boekhout et al., 1997, 1998; Fan et al., 1994; Kwon-Chung, 1998). Our results, which concur with those studies, indicate the presence of two genetic entities; there is one base-position difference in the D1/D2 region and four differences in the ITS1 region but no differences in the 5.8 or ITS2 regions.

To further explore the use of the ITS region for species separations, we examined C. ater, Cryptococcus magnus, Filobasidium elegans and Filobasidium floriforme, whose D1/D2 sequences are identical (Fig. 1). $C$. ater and C. magnus are physiologically similar, although the two strains can be separated by their abilities to utilize D-glucosamine (Fell \& Statzell-

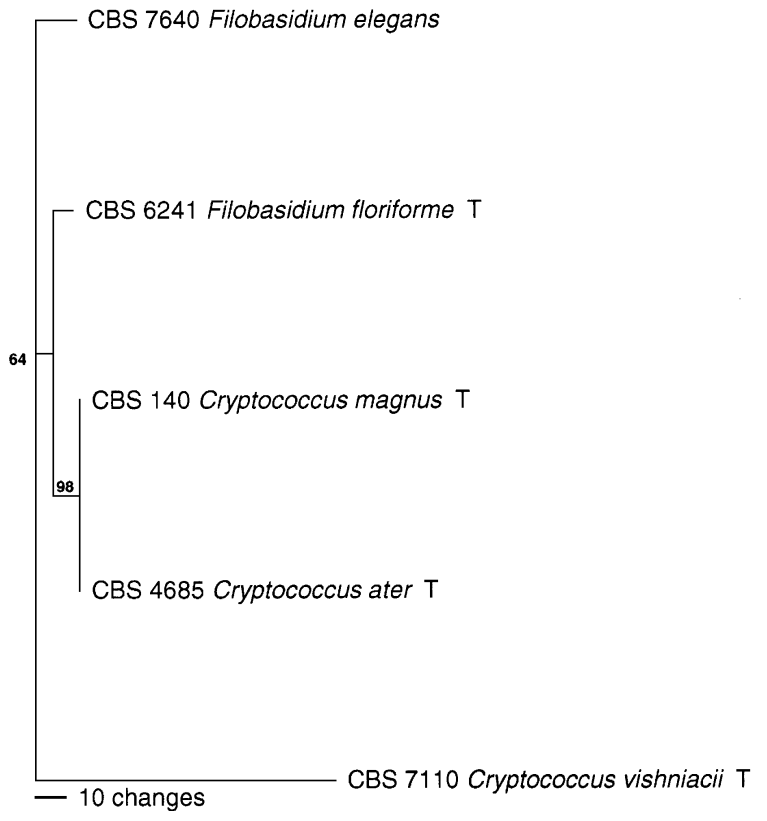

Fig. 6. Filobasidium elegans and related species as viewed by sequence analysis of the internal transcribed spacer region (single most parsimonious tree). Number of characters, 658; constant characters, 531; parsimony-uninformative characters, 113; parsimony-informative characters, 14. Tree length, 138; consistency index, 0.9855; homoplasy index, 0.0145. Numbers on branches, bootstrap percentages from 1000 branch and bound replications. T, Type strain. Bar, 10 changes.

Tallman, 1998). A major difference between C. ater, $C$. magnus and $F$. floriforme is growth on nitrate and nitrite (Kurtzman \& Fell, 1998). F. elegans is dissimilar from those three taxa in that it is unable to assimilate several compounds such as cellobiose, lactose, raffinose, melezitose, rhamnose, salicin and inositol (Fell \& Statzell-Tallman, 1998; Kwon-Chung, 1998). The similarity of LrDNA sequences led Guého et al. (1993) to postulate that $C$. ater is an anamorphic state of F. elegans. ITS analysis (Fig. 6) presents a different picture: $C$. ater and $C$. magnus represent a single species (C. magnus has nomenclatural priority); $F$. elegans, F. floriforme and C. magnus, however, show significant differences in the ITS region, which confirms the presence of separate species. As indicated in Figs 1-3, there are several additional species with identical D1/D2 sequences that require ITS analysis (for example, Sporobolomyces oryzicola/ Sporobolomyces coprosmae, Rhodotorula futronensis/ Rhodotorula fujisanensis and B. pseudoalba/C. cellulolyticus).

Our experience, to date, suggests that strains that differed by two or more nucleotides in the D1/D2 region represented different taxa. In cases where we examined multiple strains within a species (Tables 1-3), D1/D2 sequences were identical. Taxonomic differences were not as clear when phenotypic analyses suggested distinct taxa, in contrast to the D1/D2 data, which were identical or differed by one nucleotide. The 
examples we have presented indicate that the taxonomy can be clarified by ITS analysis. In addition to the ITS region, the IGS region is useful and may be required for strain separations as demonstrated with Xanthophyllomyces, Phaffia (Fell \& Blatt, 1999) and Mrakia (Diaz \& Fell, 2000).

\section{Conclusions}

A goal of the research was to examine the phylogenetic diversity of yeasts among the Ustilaginomycetes, Urediniomycetes and Hymenomycetes. The results confirm some accepted concepts; viz., the yeasts are a heterogeneous group of organisms and that many genera are artificial assemblages. For example, the genus Cryptococcus occurs in the following Hymenomycetes clades: Tremellales, Trichosporonales, Filobasidiales and Cystofilobasidiales. Similarly, species of Rhodotorula occur in the Microbotryum, Sporidiobolus and Erythrobasidium clades of the Urediniomycetes and the Ustilaginales and Microstromatales clades of the Ustilaginomycetes. In contrast, some genera such as Kondoa, Cystofilobasidium and Fellomyces may be phylogenetically distinct, as they are limited in distribution to specific clades and clusters. Consequently, the systematics of species must be interpreted in the context of the relationship to other species as viewed in these clusters and clades. A strength, therefore, of sequence analysis is that it provides testable hypotheses regarding the biology of these yeasts. One might anticipate that yeasts in clusters with Kondoa, Sporidiobolus or Cystofilobasidium will be found to exhibit similar phenotypic characteristics, such as cellular ultrastructure and life cycles. Similarly, study of the ustilaginaceous yeasts may reveal their biological relationships to the plant-parasitic and saprophytic filamentous fungi. In particular, are these yeasts anamorphic stages of parasitic filamentous teleomorphs or do they represent independent saprophytic members of this ecological niche?

Another goal of the research was to provide a method for determining yeast biodiversity. An understanding of the role and diversity of basidiomycetous yeasts in natural habitats has been slow to develop because of the difficulties of identification procedures. The urgent need for biodiversity studies is due to the worldwide rapid degradation of ecosystems. Industry and academics require precise identifications for various process- and physiologically/biochemically-oriented studies. Most species of yeasts can be directly identified by $\mathrm{D} 1 / \mathrm{D} 2$ sequence analysis, alignment of the GenBank data, and placement within the appropriate phylogenetic tree. Alternatively, species can be identified via the ITS region, although a complete ITS database has not been developed and evaluated. Use of the database would have particular value for the phylogenetic placement of new, undescribed yeasts. In addition, through comparative analysis of the database, PCR primers and hybridization probes could be designated for the rapid identification of known species.

\section{ACKNOWLEDGEMENTS}

This research was supported by the National Science Foundation (Ocean Science Division). David Yarrow provided the CBS strains. The Latin diagnosis was prepared by Walter Gams (CBS). C. P. Kurtzman (USDA, Peoria) provided strains and an insightful review of a draft manuscript. Helen Vishniac (Oklahoma State University) and Brian Steffenson (North Dakota State University) contributed strains. Gina Blatt (University of Miami) furnished technical assistance.

\section{REFERENCES}

Bandoni, R. J. (1995). Dimorphic Heterobasidiomycetes: taxonomy and parasitism. Stud Mycol 39, 13-28.

Barnett, J. A., Paine, R. W. \& Yarrow, D. (1990). Yeasts: Characteristics and Identification, 2nd edn. Cambridge: Cambridge University Press.

Bauer, R. \& Oberwinkler, F. (1991). The colacosomes: new structures at the host-parasite interface of a mycoparasitic basidiomycete. Bot Acta 104, 53-57.

Bauer, R., Oberwinkler, F. \& Deml, G. (1989). Ultrastruktur der Basidiensepten phragmobasidialer Brandpilz. Z Mykol 55, 163-168.

Bauer, R., Oberwinkler, F. \& Vanky, K. (1997). Ultrastructural markers and systematics in smut fungi and allied taxa. Can $J$ Bot 75, 1273-1314.

Begerow, D., Bauer, R. \& Oberwinkler, F. (1997). Phylogenetic studies on the nuclear large subunit ribosomal DNA of smut fungi and related taxa. Can J Bot 75, 2045-2056.

Begerow, D., Bauer, R. \& Boekhout, T. (1999). Phylogenetic placements of Ustilaginomycetous anamorphs as deduced from nuclear LSU rDNA sequences. Mycol Res (in press).

Boekhout, T. \& Nakase, T. (1998). Bullera Derx. In The Yeasts, a Taxonomic Study, 4th edn, pp. 731-741. Edited by C. P. Kurtzman \& J. W. Fell. Amsterdam: Elsevier.

Boekhout, T., Fonseca, A. \& Batenburg-van der Vegte, W. H. (1991). Bulleromyces genus novum (Tremellales) a teleomorph for Bullera alba, and the occurrence of mating in Bullera variabilis. Antonie Leeuwenhoek 59, 81-93.

Boekhout, T., Yamada, Y., Weijman, A. C. M., Roeijmans, H. J. \& Batenburg-van der Vegte, W. H. (1992). The significance of coenzyme Q, carbohydrate composition and septal ultrastructure for the taxonomy of ballistoconidia-forming yeasts and fungi. Syst Appl Microbiol 15, 1-10.

Boekhout, T., Fell, J. W. \& O'Donnell, K. (1995). Molecular systematics of some yeast-like anamorphs belonging to the Ustilaginales and Tilletiales. Stud Mycol 38, 175-183.

Boekhout, T., Belkum, A., van Leenders, A. C., Verbrugh, H. A., Mukamurangwa, P., Swinne, D. \& Scheffers, W. A. (1997). Molecular typing of Cryptococcus neoformans: taxonomic and epidemiological aspects. Int J Syst Bacteriol 47, 432-442.

Boekhout, T., Bandoni, R. J., Fell, J. W. \& Kwon-Chung, K. J. (1998). Discussion of teleomorphic and anamorphic genera of heterobasidiomycetous yeasts. In The Yeasts, a Taxonomic Study, 4th edn, pp. 609-626. Edited by C. P. Kurtzman \& J. W. Fell. Amsterdam: Elsevier.

Chen, C. (1998). Morphological and molecular studies in the genus Tremella. Bibl Mycol 174, 1-225.

Diaz, M. R. \& Fell, J. W. (2000). Systematics of psychrophilic yeasts in the genus Mrakia based on ITS and IGS rDNA sequence analysis. Antonie Leeuwenhoek 77, 7-12. 
Dietrichson, E. (1954). Étude d'une collection norvégienne de levures. Ann Parasitol Hum Comp 29, 271-288, 460-498.

Fan, M., Currie, B. P., Gutell, R. R., Ragan, M. A. \& Casadevall, A. (1994). The $16 \mathrm{~S}$-like, $5.8 \mathrm{~S}$ and 23S-like rRNAs of the two varieties of Cryptococcus neoformans: sequence, secondary structure, phylogenetic analysis and restriction fragment polymorphisms. J Med Vet Mycol 32, 163-180.

Fell, J. W. (1995). rDNA targeted oligonucleotide primers for the identification of pathogenic yeasts in a polymerase chain reaction. J Ind Microbiol 14, 475-477.

Fell, J. W. \& Blatt, G. (1999). Separation of strains of the yeasts Xanthophyllomyces dendrorhous and Phaffia rhodozyma based on rDNA IGS and ITS sequence analysis. $J$ Ind Microbiol Biotechnol 21, 677-681.

Fell, J. W. \& Kurtzman, C. P. (1990). Nucleotide sequence analysis of a variable region of the large subunit rRNA for identification of marine occurring yeasts. Curr Microbiol 21, 295-300.

Fell, J. W. \& Statzell-Tallman, A. (1998). Cryptococcus Vuillemin. In The Yeasts, a Taxonomic Study, 4th edn, pp. 472-767. Edited by C. P. Kurtzman \& J. W. Fell. Amsterdam: Elsevier.

Fell, J. W., Boekhout, T. \& Freshwater, D. W. (1995). The role of nucleotide analysis in the systematics of the yeast genera Cryptococcus and Rhodotorula. Stud Mycol 38, 129-146.

Fell, J. W., Roeijmans, H. \& Boekhout, T. (1999). Cystofilobasidiales, a new order of basidiomycetous yeasts. Int J Syst Bacteriol 49, 907-913.

Fonseca, A., Sampaio, J. P., Inacio, J. \& Fell, J. W. (2000a). Emendation of the basidiomycetous yeast genus Kondoa and the description of Kondoa aeria sp. nov. Antonie Leeuwenhoek (in press).

Fonseca, A., Scorzetti, G. \& Fell, J. W. (2000b). Diversity in the yeasts Cryptococcus albidus and related species as revealed by ribosomal DNA sequence analysis. Can J Microbiol 46, 7-27.

Golubev, W. I. (1999). Mastigobasidium, a new teleomorphic genus for the perfect state of ballistosporous yeast Bensingtonia intermedia. Int J Syst Bacteriol 49, 1301-1305.

Goto, S. (1963). On a new yeast genus Naganishia. J Ferment Technol 41, 459-462.

Guého, E., Kurtzman, C. P. \& Peterson, S. W. (1989). Evolutionary affinities of heterobasidiomycetous yeasts estimated from $18 \mathrm{~S}$ and $25 \mathrm{~S}$ ribosomal RNA sequence divergence. Syst Appl Microbiol 12, 230-236.

Guého, E., Smith, M. Th., de Hoog, G. S., Billon-Grand, G., Christen, R. \& Batenburg-van der Vegte, W. H. (1992). Contributions to a revision of the genus Trichosporon. Antonie Leeuwenhoek 61, 289-316.

Guého, E., Improvisi, L., Christen, R. \& de Hoog, G. S. (1993). Phylogenetic relationships of Cryptococcus neoformans and some related basidiomycetous yeasts determined from partial large subunit rRNA sequences. Antonie Leeuwenhoek 63, 175-189.

Guého, E., Midgley, G. \& Guillot, J. (1996). The Genus Malassezia with descriptions of four new species. Antonie Leeuwenhoek 69 , 337-355.

Guillot, J. \& Guého, E. (1995). The diversity of Malassezia yeasts confirmed by rRNA sequence and nuclear DNA comparisons. Antonie Leeuwenhoek 67, 297-314.

Hamamoto, M., Sugiyama, J. \& Komagata, K. (1987). DNA-DNA reassociation studies of strains in the genera Rhodosporidium and Rhodotorula. J Gen Appl Microbiol 33, 57-63.
Haynes, K. A., Westerneng, T. J., Fell, J. W. \& Moens, W. (1995). Detection and identification of pathogenic fungi by polymerase chain reaction amplification of large subunit ribosomal DNA. $J$ Med Vet Mycol 33, 319-325.

Ikeda, R., Shinoda, T., Fukazawa, Y. \& Kaufman, L. (1982). Antigenic characterization of Cryptococcus neoformans serotypes and its application to serotyping of clinical isolates. $J$ Clin Microbiol 16, 22-29.

Johnson, E. A. \& Phaff, H. J. (1978). Rhodotorula fujisanensis, a new taxonomic combination. Curr Microbiol 1, 223-225.

Kreger-van Rij, N. J. W. \& Veenhuis, M. (1971). A comparative study of the cell wall structure of basidiomycetous and related yeasts. J Gen Microbiol 68, 87-95.

Kurtzman, C. P. \& Fell, J. W. (1998). The Yeasts, a Taxonomic Study, 4th edn. Amsterdam: Elsevier.

Kwon-Chung, K. J. (1998). Filobasidiella Kwon-Chung. In The Yeasts, a Taxonomic Study, 4th edn, pp. 656-662. Edited by C. P. Kurtzman \& J. W. Fell. Amsterdam: Elsevier.

McLaughlin, E., Frieders, M. \& Lu, H. (1995). A microscopist's view of heterobasidiomycete phylogeny. Stud Mycol 38, 91-110.

Magee, B. B., D'Souza, T. M. \& Magee, P. T. (1987). Strain and species identification by restriction fragment length polymorphisms in the ribosomal DNA repeat of Candida species. $J$ Bacteriol 169, 1639-1643.

Mannarelli, B. M. \& Kurtzman, C. P. (1998). Rapid identification of Candida albicans and other human pathogenic yeasts by using short oligonucleotides in a PCR. J Clin Microbiol 36, 1634-1641.

Mitchell, T. G., Freedman, E. Z., White, T. J. \& Taylor, J. W. (1994). Unique oligonucleotide primers in PCR for identification of Cryptococcus neoformans. J Clin Microbiol 32, 253-255.

Moore, R. T. (1980). Taxonomic proposals for the classification of marine yeasts and other yeast-like fungi including the smuts. Bot Mar 23, 361-373.

Moore, R. T. (1998). Cytology and ultrastructure of yeasts and yeast-like fungi. In The Yeasts, a Taxonomic Study, 4th edn, pp. 33-44. Edited by C. P. Kurtzman \& J. W. Fell. Amsterdam: Elsevier.

Nakase, T., Takematsu, A. \& Yamada, Y. (1993). Molecular approaches to the taxonomy of ballistosporous yeasts based on the analysis of the partial nucleotide sequences of $18 \mathrm{~S}$ ribosomal ribonucleic acids. J Gen Appl Microbiol 39, 107-134.

O'Donnell, K. L. \& McLaughlin, D. J. (1984). Ultrastructure of meiosis in Ustilago maydis. Mycologia 76, 468-485.

Prillinger, H., Dörfler, C., Laaser, G. \& Hauska, G. (1990). Ein Beitrag zur Systematik und Entwicklungsbiologie Höherer Pilze: Hefe-Typen der Basidiomyceten. Teil III : Ustilago-Typ. Z Mykol 56, 251-278.

Prillinger, H., Deml, G., Dörfler, C., Laaser, G. \& Lockau, W. (1991). Ein Beitrag zur Systematik und Entwicklungsbiologie Höherer Pilze: Hefe-Typen der Basidiomyceten. Teil II : MicrobotryumTyp. Bot Acta 104, 5-17.

Prillinger, H., Oberwinkler, F., Umile, C., Tlachac, K., Bauer, R., Dörfler, C. \& Taufratzhofer, E. (1993). Analysis of cell wall carbohydrates (neutral sugars) from ascomycetous and basidiomycetous yeasts with and without derivatization. J Gen Appl Microbiol 39, 1-14.

Roeijmans, H., Prillinger, H., Umile, C., Sugiyama, J., Nakase, T. \& Boekhout, T. (1998). Analysis of carbohydrate composition of cell walls and extracellular carbohydrates. In The Yeasts, a Taxonomic Study, 4th edn, pp. 99-101. Edited by C. P. Kurtzman \& J. W. Fell. Amsterdam: Elsevier. 
Sampaio, J. P. \& Fonseca, A. (1995). Physiological aspects in the systematics of heterobasidiomycetous yeasts. Stud Mycol 38, $29-46$.

Sampaio, J. P., Bauer, R., Begerow, D. \& Oberwinkler, F. (1999). Occultifur externus sp. nov., a new species of simple-pored auricularioid heterobasidiomycete from plant litter in Portugal. Mycologia 91, 1094-1104.

Shinoda, T., Ikeda, R., Nishikawa, A. \& Fukazawa, Y. (1980). The serological, chemical and physiochemical analyses of cryptococcal capsular polysaccharides. Jpn J Med Mycol 21, 230-238.

Simmons, R. B. \& Ahearn, D. G. (1987). Cell wall ultrastructure and diazonium blue B reaction of Sporopachydermia quercuum, Bullera tsugae, and Malassezia spp. Mycologia 79, 38-43.

Statzell-Tallman, A. \& Fell, J. W. (1998). Leucosporidium Fell et al. In The Yeasts, a Taxonomic Study, 4th edn, pp. 670-675. Edited by C. P. Kurtzman \& J. W. Fell. Amsterdam: Elsevier.

Sugita, T., Nishikawa, A. \& Shinoda, T. (1992). DNA relatedness among three varieties of Cryptococcus albidus. J Gen Appl Microbiol 38, 83-86.

Sugiyama, J. \& Suh, S.-O. (1993). Phylogenetic analysis of basidiomycetous yeasts inferred from small subunit ribosomal DNA sequence. J Gen Microbiol 139, 1595-1598.

Suh, S.-O. \& Nakase, T. (1995). Phylogenetic analysis of the ballistosporogenous anamorphic genera Udeniomyces and Bullera, and related basidiomycetous yeasts, based on $18 \mathrm{~S}$ rDNA sequence. Microbiology 141, 901-906.

Suh, S.-O. \& Sugiyama, J. (1993). Phylogeny among the basidiomycetous yeasts inferred from small subunit ribosomal DNA sequence. J Gen Microbiol 139, 1595-1598.

Swann, E. A. \& Taylor, J. W. (1995a). Phylogenetic diversity of yeast-producing basidiomycetes. Mycol Res 99, 1205-1210.

Swann, E. A. \& Taylor, J. W. (1995b). Toward a phylogenetic systematics of the Basidiomycota: integrating yeasts and filamentous basidiomycetes using 18S rRNA gene sequences. Stud Mycol 38, 147-162.
Swann, E. A. \& Taylor, J. W (1995c). Phylogenetic perspectives on basidiomycete systematics: evidence from the 18S rRNA gene. Can J Bot (suppl. 1) 73, S862-S868.

Swann, E. C., Frieders, E. M. \& McLaughlin, D. J. (1999). Microbotryum, Kriegeria and the changing paradigm in basidiomycete classification. Mycologia 91, 51-66.

Vancanneyt, M., Coopman, R., Tytgat, R., Hennebert, G. L. \& Kersters, K. (1994). Whole-cell protein patterns, DNA base compositions and coenzyme Q types in the yeast genus Cryptococcus Kützing and related taxa. Syst Appl Microbiol 17, 65-75.

Van de Peer, Y., Hendriks, L., Goris, A., Neefs, J. M., Vancanneyt, M., Kersters, K., Berny, J. F., Hennebert, G. L. \& De Wachter, R. (1992). Evolution of basidiomycetous yeasts as deduced from small ribosomal subunit RNA sequences. Syst Appl Microbiol 15, 250-258.

Vaughan-Martini, A. (1991). Intraspecific discontinuity within the yeast species Cryptococcus albidus as revealed by nDNA/nDNA reassociation. Exp Mycol 15, 140-145.

Walsh, T. J., Francesconi, A., Kasai, M. \& Chanock, S. J. (1995). PCR and single-strand conformational polymorphism for recognition of medically important opportunistic fungi. $J$ Clin Microbiol 33, 3216-3220.

Weijman, A. C. M. \& Golubev, W. I. (1987). Carbohydrate patterns and taxonomy of yeasts and yeast-like fungi. Stud Mycol 30, 361-371.

Wells, K. (1994). Jelly fungi, then and now! Mycologia 86, 18-48. Yamada, Y. \& Kawasaki, H. (1989). The molecular phylogeny of the Q8-equipped basidiomycetous yeasts genera Mrakia Yamada et Komagata and Cystofilobasidum Oberwinkler et Bandoni based on the partial sequences of $18 \mathrm{~S}$ and $26 \mathrm{~S}$ ribosomal ribonucleic acids. J Gen Appl Microbiol 35, 173-183.

Yamada, Y. \& Nakagawa, Y. (1992). The phylogenetic relationships of some heterobasidiomycetous yeast species based on the partial sequences of $18 \mathrm{~S}$ and $26 \mathrm{~S}$ ribosomal RNAs. J Gen Appl Microbiol 38, 559-565. 